\title{
Perspectives in cancer chemotherapy, in vitro and in vivo experiments
}

Ph.D. Thesis

Helga Engi

Department of Medical Microbiology and Immunobiology

University of Szeged 


\section{TABLE OF CONTENTS}

1. INTRODUCTION

1.1. Cancer incidence and mortality in Europe and Hungary 2

1.2. Strategies for cancer treatment 4

$\begin{array}{ll}\text { 1.3. Cellular drug resistance mechanisms } & 6\end{array}$

1.4. ABC transporters 8

$\begin{array}{ll}\text { 1.5. Transported substrates of ABC transporters } & 10\end{array}$

1.6. Reversal of MDR 11

1.7. Cancer chemoprevention; the oncomodulatory effect of human cytomegalovirus 12

2. AIMS OF THE STUDY 14

3. MATERIALS AND METHODS

3.1. Chemicals 16

$\begin{array}{ll}\text { 3.2. Cell cultures } & 17\end{array}$

3.3. Animals 17

$\begin{array}{ll}\text { 3.4. Virus } & 17\end{array}$

3.5. Assay for antiproliferative and cytotoxic effect 17

3.6. Flow-cytometric assay for R123 accumulation in tumour cells 18

3.7. Checkerboard microplate methods as a model for combination therapy 18

3.8. Cellular accumulation and cytotoxicity of doxorubicin in vitro 18

3.9. In vivo studies 19

3.10. Apoptosis assays 19

3.11. Anti-promotion experiments 20

4. RESULTS

4.1. Antiproliferative and cytotoxic effect by tested compounds 21

4.2. Reversal of MDR1 by flow-cytometric assay 22

4.3. Interaction of resistance modifier with anticancer drugs $\quad 29$

4.4. Cellular accumulation and cytotoxicity of doxorubicin in vitro 31

4.5. In vivo doxorubicin accumulation study in mouse MDR cells 32

4.6. Apoptosis induction of some resistance modifiers 33

4.7. Anti-promotion effect of plant derivatives 35

5. DISCUSSION 36

6. NEW STATEMENTS 42

7. ÖSSZEFOGLALÓ 44

8. ACKNOWLEDGEMENTS 46

9. REFERENCES 47

10. APPENDIX 


\section{INTRODUCTION}

\subsection{Cancer incidence and mortality in Europe and Hungary}

Cancer is a major public health problem worldwide. Currently, after cardiovascular diseases, cancer is the second leading cause of death in European countries (1).

Figure 1. Estimated incidence of cancer in Europe, 2006 (Ref.: 2)

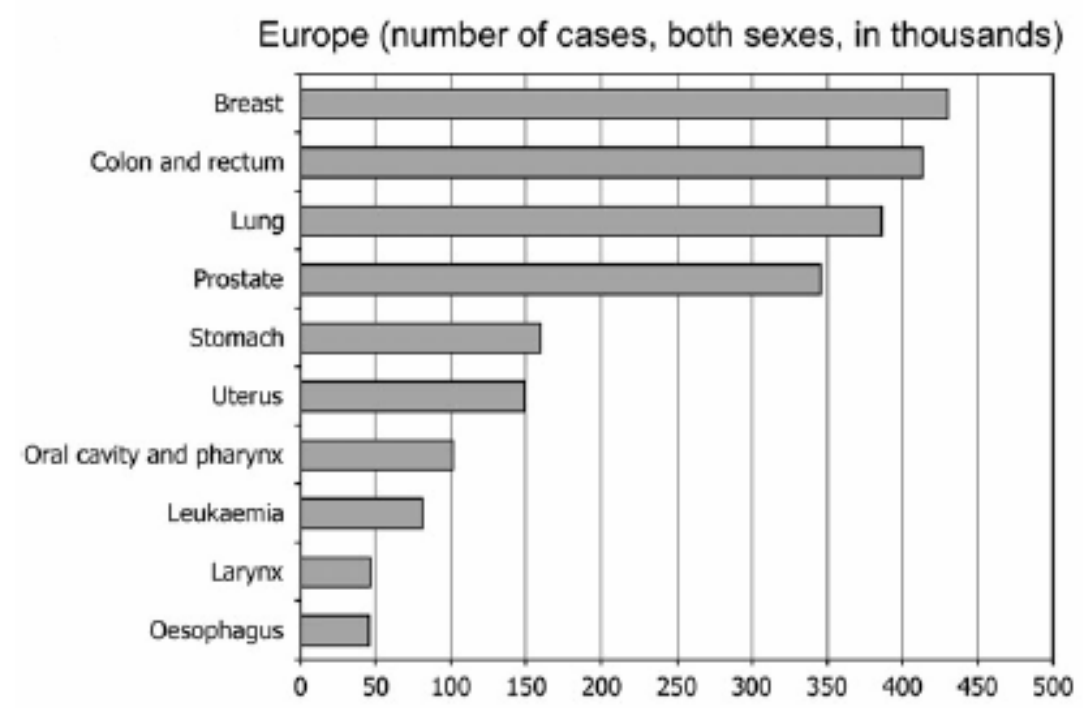

In 2006 in Europe, there were an estimated more than 3 million incidence cases of cancer diagnosed (2). Breast cancer has now become the most common form of cancer diagnosed in Europe, both sexes combined (Figure 1).

Figure 2. Estimated mortality from cancer in Europe, 2006 (Ref.: 2)

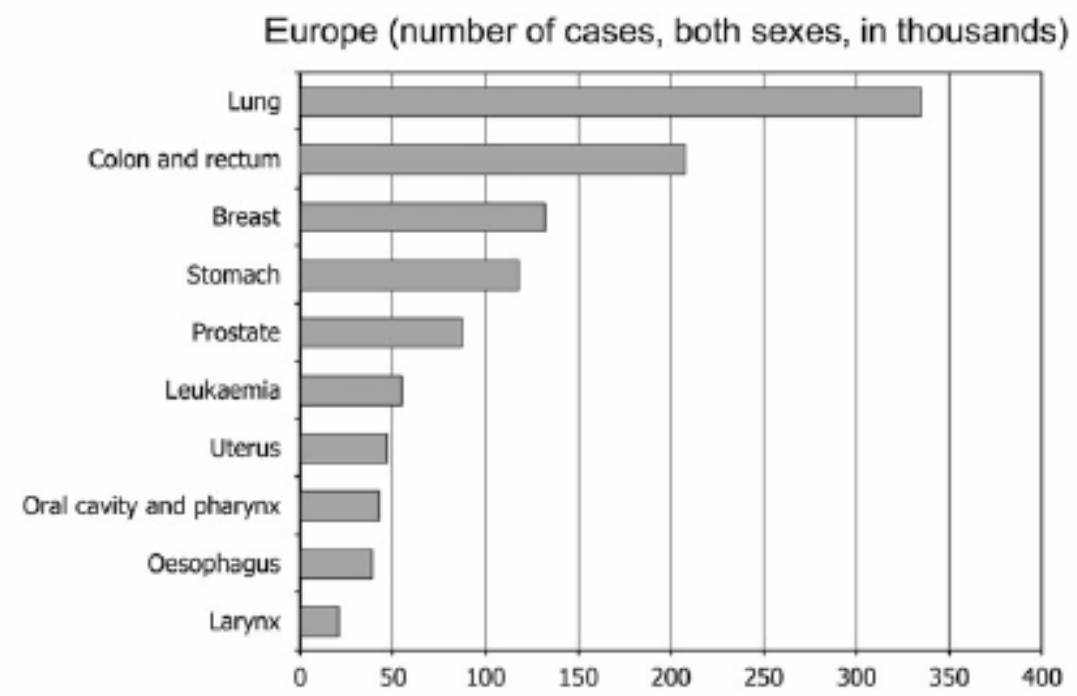

It is not only a problem for the elderly, but is also an important cause of premature mortality in the productive adult years. 
Overall, 1.7 million cancer death are estimated in Europe in 2006. The most common cause of cancer death is lung cancer (Figure 2). Colorectal cancer was the second major cause of cancer death, followed by breast cancer, which now ranked higher than stomach cancer (2).

Hungary has currently the highest cancer mortality rates for all cancer sites combined among men (Figure 3). Compared to Hungary, the situation in the Czech Republic is better and only Denmark produce worse data than Hungary (3).

\section{Figure 3. Estimated age-standardized mortality rates by area and country in Europe, 2002 (Ref.: 3)}

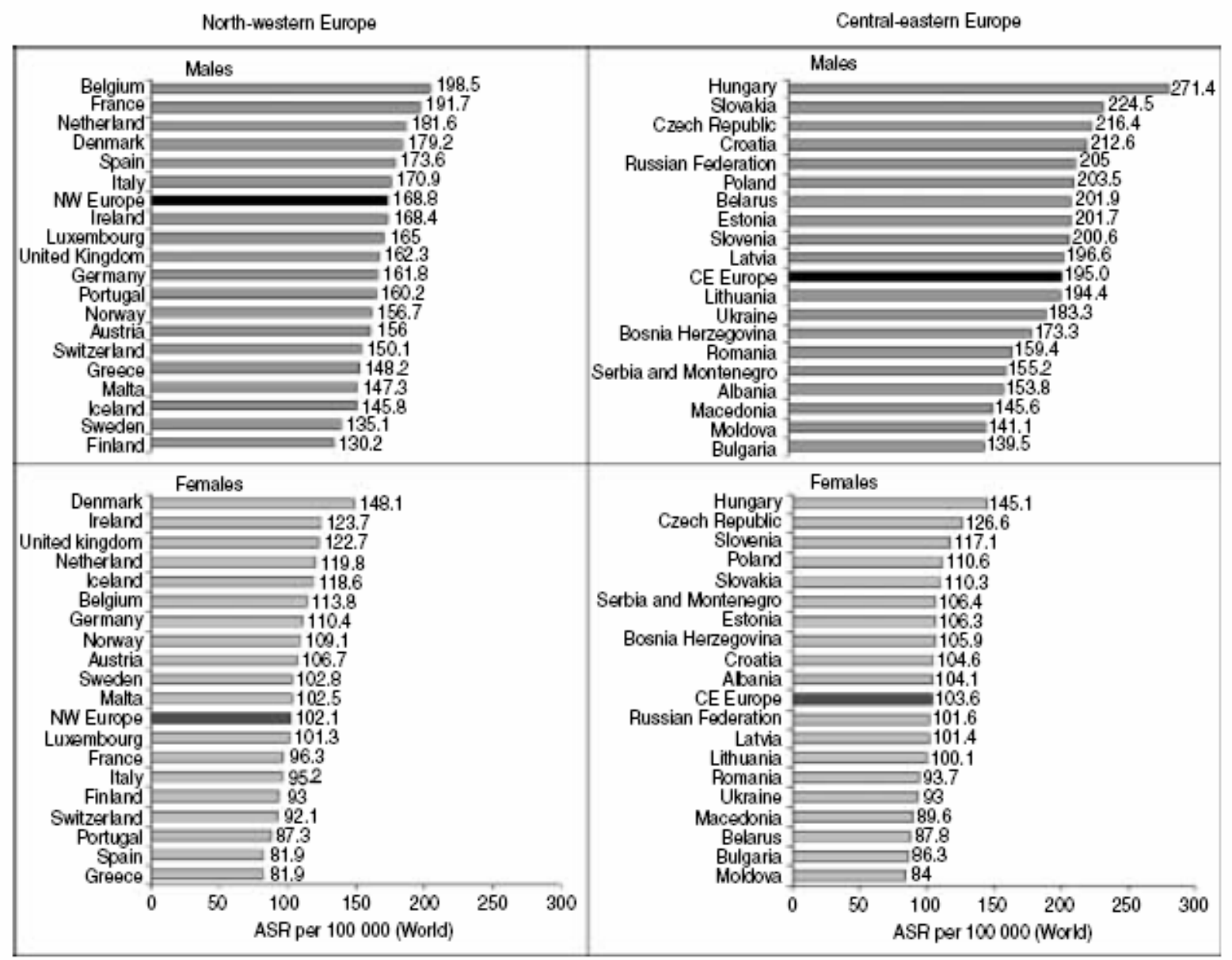

In Hungary (Table 1), the cancer mortality list is topped by lung and colorectal cancer among men and by breast and colorectal cancer among women (4).

$40 \%$ of cancer can be prevented by a healthy diet, physical activity and not using tobacco. Tobacco use is the single most important risk factor for cancer and causes a large variety of cancer types such as lung, larynx, oesophagus, stomach, bladder, oral cavity and others (5). Environmental tobacco smoke (passive smoking) causes lung cancer. Although there are still 
some open questions, there is sufficient evidence that dietary factors also play an important role in causing cancer. This applies to obesity as a compound risk factor per se as well as to the composition of the diet such as lack of fruit and vegetables and high salt intake. Lack of physical activity has a distinct role as risk factor for cancer. There is solid evidence about alcohol causing several cancer types such as oesophagus, pharynx, larynx, liver, breast, and other cancer types (6).

Table 1. Newly reported cancer cases in Hungary according to sexes in 2001 (based on the National Cancer Registry)

\begin{tabular}{rlr|rlr}
\hline \multicolumn{2}{c}{ Men } & & \multicolumn{2}{c}{ Women } \\
\hline & Cancer number & 29982 & & Cancer number & 28790 \\
& Patient number & 25660 & & Patient number & 25476 \\
& & & & 5610 \\
1 & Lung & 6099 & 1 & Breast & 3619 \\
2 & Colorectal & 3981 & 2 & Colorectal & 3307 \\
3 & *Skin & 3072 & 3 & *Skin & 2728 \\
4 & Oral cavity & 2369 & 4 & Lung & 1598 \\
5 & Prostatic & 2304 & 5 & Lymphatic and haematopoetic system \\
6 & Urinary bladder & 1436 & 6 & Cervical & 1132 \\
7 & Lymphatic and haematopoetic system & 1436 & 7 & Uterine & 1119 \\
8 & Stomach & 1248 & 8 & Ovarian & 1027 \\
9 & Laryngeal & 1043 & 9 & Stomach & 927 \\
10 & Kidney & 886 & 10 & Pancreas & 703 \\
& & 11 & Melanoma & 701 \\
\hline
\end{tabular}

*without malignant melanoma

One-fifth of cancers worldwide are due to chronic infections, mainly from Hepatitis B viruses HBV (7) (causing liver), human papilloma viruses HPV (8) (causing cervix), Helicobacter pylori (9) (causing stomach) and human immunodeficiency virus HIV (10) (Kaposi sarcoma and lymphomas).

\subsection{Strategies for cancer treatment}

Cancer is a class of diseases characterized by an imbalance in the mechanisms of cellular proliferation (growth) and apoptosis (programmed cell death). When left untreated, this imbalance results in the growth of cancerous malignancies, including solid tumours and blood-borne disease, among others, and the resulting death of the host organism. Once cancer is detected, it is removed, if possible (in the case of accessible solid tumours), and treatment is initiated. Surgery, radiotherapy, immunotherapy, hormonal therapy and chemotherapy are common treatment methods (11). Approximately $40 \%$ of cancer patients can be treated surgically, and the great majority of patients need chemotherapy. A great number of anticancer agents are under clinical investigation at this moment. Some of them belong to 
classic groups of chemotherapy (Table 2), but others are the first of new families of drugs (12).

Table 2. Useful chemotherapeutic agents (Ref. : 13)

\begin{tabular}{|l|l|l|}
\hline $\begin{array}{l}\text { Alkylating agents } \\
\text { Nitrogen mustard } \\
\text { (Chlorambucil, Cyclophosphamide) }\end{array}$ & $\begin{array}{l}\text { Antimetabolites } \\
\text { Folic acid analogue } \\
\text { (Methotrexate) }\end{array}$ & $\begin{array}{l}\text { Natural products } \\
\text { (Vitotic inhibitor }\end{array}$ \\
\hline $\begin{array}{l}\text { Nitrosourea } \\
\text { (Carmustine, Lomustine) }\end{array}$ & $\begin{array}{l}\text { Pyrimidine analogue } \\
\text { (Fluorouracil) }\end{array}$ & $\begin{array}{l}\text { Microtubule polymer } \\
\text { stabilizer }\end{array}$ \\
\hline $\begin{array}{l}\text { Metal salt } \\
\text { (Cisplatin, Carboplatin) }\end{array}$ & $\begin{array}{l}\text { Purin analogue } \\
\text { (Fludarabine) }\end{array}$ & $\begin{array}{l}\text { Podophyllum derivative } \\
\text { (Etoposide) }\end{array}$ \\
\hline $\begin{array}{l}\text { Hormone / hormone antagonists } \\
\text { (Tamoxifen, Prednisone, } \\
\text { Flutamide,Leuprolide) }\end{array}$ & $\begin{array}{l}\text { Miscellaneous agents } \\
\text { (Hydroxyurea, } \\
\text { Procarbazine, Mitotane) }\end{array}$ & $\begin{array}{l}\text { Antibiotic } \\
\text { (Daunorubicin, Doxorubicin, } \\
\text { Epirubicin) }\end{array}$ \\
\hline
\end{tabular}

Some anticancer drugs are cell cycle phase-specific (13) e.g. Antimetabolites (Cytarabine, Fluorouracil, Methotrexate, Thioguanine, Fludarabine); Miscellaneous (Hydroxyurea); Natural products (Etoposide, Paclitaxel, Vinblastine, Vincristine); other are cell cycle-specific e.g. Antibiotics (Daunorubicin, Doxorubicin); or cell cycle-non-specific agents e.g. Alkylating agents (Nitrogen mustard, Nitrosourea).

Although a number of anticancer drugs have been commercialized, the need for more effective ones continues to exist, because the most common tumours are resistance to available drugs. In fact, multidrug resistance (MDR) remains a significant problem for the effectiveness of cancer treatment (see Section 1.3).

An alternative mechanism for cancer therapy is the selective induction of apoptosis by various compounds (14). Several studies have shown that most chemotherapeutic agents exert their anticancer activity by inducing programmed cell death, which is an essential physiological process required to eliminate abnormal cells (15-17). Compounds, which regulate and overcome the apoptosis deficiency of cancer cells, are of great therapeutic importance, and the development of apoptosis-modulating agents has become an important approach for the discovery of new antitumour drugs.

Induction of apoptosis in tumour cells can occur by at least three different pathway involving one extrinsic (cell surface receptors), and two intrinsic pathways (the mitochondria and the endoplasmic reticulum) which, may or may not be initiated separately or concurrently (18, 19). Chemotherapeutic drugs (20), cellular conditions (serum starvation, radiation), the presence of mutated p53 can trigger the apoptotic response via one of the three pathways (21). 
The apoptosis defines a genetically encoded cell death program, which is morphologically, biochemically and molecularly distinct from necrosis (Figure 4).

Figure 4: Morphological and biochemical changes during apoptosis and necrosis (Ref.: 22)

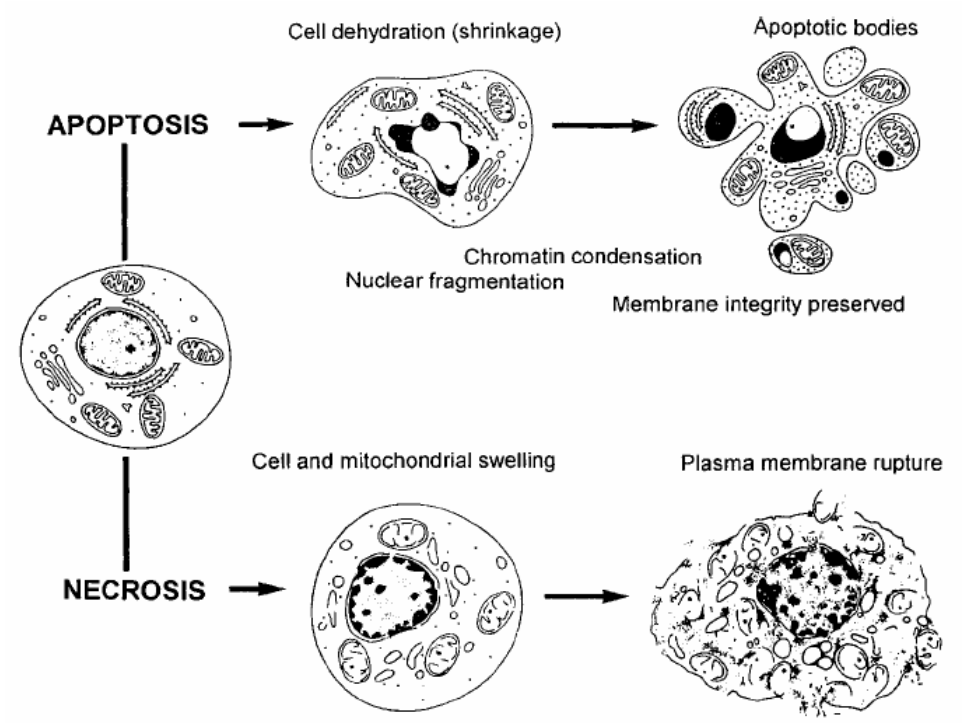

While apoptosis is characterized by an active participation (23) of the affected cell in its own demise (e.g. activation of endonucleases, which cleave DNA at the internucleosomal section), necrosis is a passive, catabolic and degenerative process, which always triggers an inflammatory reaction in the tissue.

\subsection{Cellular drug resistance mechanisms}

The ability of cancer cells to become cross-resistance to structurally and functionally

Table 3. (Ref.: 24)

\begin{tabular}{ll}
\hline \multicolumn{2}{c}{ Mechanisms of drug resistance } \\
\hline Mechanism & Individual process \\
\hline Cell kinetic resistance & Tumor growth \\
\hline Pharmacokinetic & Poor absorption \\
resistance & Excessive metabolism \\
& Poor penetration to certain sites \\
& Blood supply of the tumor \\
& Drug diffusion \\
\hline Cellular drug & Increased drug efflux \\
resistance & Decreased drug uptake \\
& Sequestration of drugs \\
& Alterations in drug targets \\
& Activation of detoxifying systems \\
& Increased repair of drug-induced DNA damage \\
& Blocked apoptosis \\
& Disruption in signaling pathways \\
& Alterations of factors involved in cell cycle regulation \\
\hline
\end{tabular}

mww.drugdiscoverytoday.com unrelated anticancer drugs is known as multidrug resistance (MDR). MDR is a major cause for the failure of chemotherapy in the treatment of cancer patients (24). It has been recognized that MDR is multifactorial and factors that affect response to anticancer chemotherapy include cell kinetic (25), pharmacokinetic (26) and cellular drug resistance mechanisms (Table 3).

Cellular mechanisms are categorized in terms of alterations in the biochemistry of

malignant cells (27). Such mechanisms can be further classified into two major categories: non-classical MDR phenotypes and transport-based classical MDR phenotypes. 


\section{I. $\quad$ Non-classical MDR phenotypes}

The term non-classical MDR is used to describe non-transport based mechanisms that affect multiple drug classes. This type of resistance can be caused by altered activity of specific enzyme systems (such as glutathione S-transferease (GST) and topoisomerases (Topo I and II)), which can decreased the cytotoxic activity of drugs in a manner independent of intracellular drug concentrations, which remain unaltered. In addition, changes in the apoptotic pathways can also reduce chemosensitivity since most anticancer drugs are exert their cytotoxic effects via apoptotic processes (27).

\section{Drug resistance mediated by detoxification mechanism of the drug in the cells} The cellular GST system is a critical component of detoxification of cytostatics in the cells. Glutathione (GSH), a non-protein thiol, can interact via its thiol with the reactive site of a drug, resulting in conjugation of the drug with GSH (28). The conjugate is less active and more water-soluble, and it is excluded from the cell with the participation of transporter proteins. Activation of these enzymes can cause cellular drug resistance. Increased levels of GSH were found in several resistance cell lines $(29,30)$.

\section{Drug resistance mediated by alterations of drug targets or by enhancement of} target repair

Topoisomerases are intrinsically involved in the process of DNA replication (31). Consequently, these enzymes constitute therapeutic targets in rapidly dividing tumour cells for anticancer drugs (32). Cells become resistant to topo II inhibitors such as anthracyclines either to the" under-expression" of Topo II (33) or topo II gene mutations (34).

Enhanced DNA repair is probably implicated in drug resistance to the drugs interacting with DNA, for example, to nitrosomethylurea or platinum derivatives. Resistance to BCNU (carmustine) is correlated with the expression of chloro-O-6-alkylguanine-DNAalkyl-transferase. Changes in the quantities of proteins recognizing or repairing DNA injury were found in cultured cells with altered sensitivity to platinum complexes (35).

\section{Drug resistance mediated by defective apoptotic pathways}

Anticancer drugs typically induced apoptosis. Resistance may develop with loss of genes required for cell death as p53 anti-oncogene (36) or overexpression of genes (bcl-2) that block cell death (37).

\section{II. $\quad$ Transport-based classical MDR phenotypes}

Reduced intracellular accumulation has historically been associated with overexpression of the ATP-binding cassette (ABC) transporters (38). These ABC transporters serve to pump 
anticancer drugs out of the cells, resulting in lack of intracellular levels of drug necessary for effective therapy (39).

\subsection{ABC transporters}

The ABC transporter superfamily is among the largest and most broadly expressed protein superfamilies known. In humans, 48 ABC genes that are organized into seven subfamilies (A$\mathrm{G})$ have been described, several of which are involved in well-defined genetic disorders (40). $\mathrm{ABC}$ transport proteins that have been implicated in multidrug resistance include the $170 \mathrm{kDa}$ multidrug resistance protein 1 (MDR1) also called P-glycoprotein (P-gp) (encoded by $\mathrm{ABCB} 1$ ), the $190 \mathrm{kDa}$ multidrug resistance related protein 1 (MRP1) (encoded by ABCC1). Other MRP family members that have the potential to confer multidrug resistance are MRP2 (encoded by ABCC2), MRP3 (encoded by ABCC3), MRP4 (encoded by ABCC4), MRP5 (encoded by ABCC5), MRP6 (ABCC6) and MRP7 (encoded by ABCC10) (28, 4142). Two additional members, MRP8 (ABCC11) and MRP9 (ABCC12) have been reported recently $(43,44)$.

Studies in human cancer cell lines selected for mitoxanthrone resistance resulted in the characterization of another member of the G subfamily of ABC transporters. The transporter called as breast cancer resistance protein (BCRP) or mitoxanthrone resistance gene (MXR) (encoded by $\mathrm{ABCG} 2)(45,46)$. The lung resistance protein (LRP), also known as the major vault protein, is not an $\mathrm{ABC}$ transporter but it is frequently expressed at high levels in drugresistant cell lines and tumour samples (47). Vaults are ribonucleoprotein particles that are present in the cytoplasm of most eukaryotic cells and might confer drug resistance by transporting drugs away from their intracellular targets and/or by the sequestration of drugs (48).

The role of P-gp in MDR is best characterized. P-gp occurrence in clinical tumours has been shown to occur both during diagnosis as well as during relapse. For example, P-gp was detected at the time of diagnosis in leukaemias (49); lymphomas (50); adult and childhood sarcomas (51), and neuroblastomas (52). P-gp detection also appears to correlate well with poor response to chemotherapy (53).

Although these transporters have been identified as drug-resistance proteins, they are all expressed in normal tissues important for absorption (e.g., lung and gut) metabolism and elimination (liver and kidney) (39). In addition, they have an important role in maintaining the barrier function of sanctuary site tissues (e.g., blood-brain barrier, blood-cerebral spinal fluid barrier, blood-testis barrier and the maternal-fetal barrier or placenta). 
The structures of the $\mathrm{ABC}$ transporters. The functional unit of typical $\mathrm{ABC}$ transporters

Figure 5. (Ref.: 54)

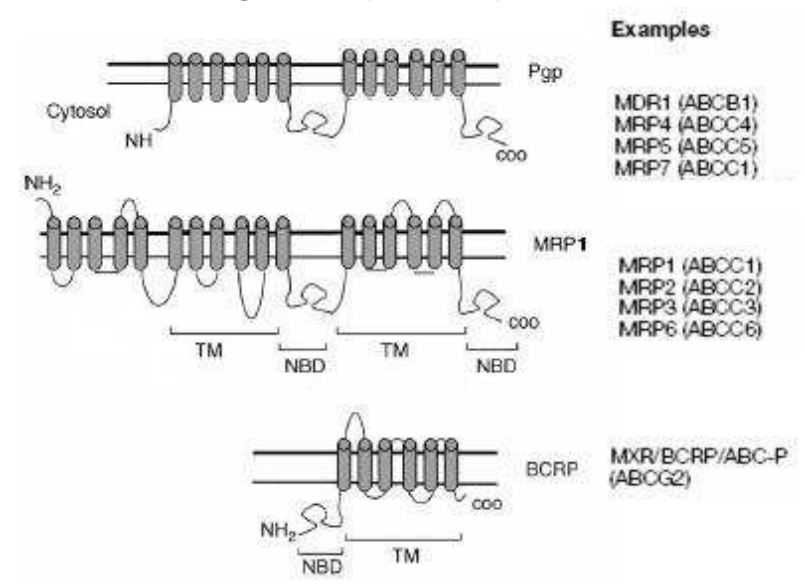

consists of two nucleotide-binding domains

(NBD), which bind and hydrolyze ATP and two transmembrane domains (TM), each with six transmembrane segments (Figure 5). The NBD harbours several conserved sequence motifs (55). From $\mathrm{NH}_{2}$ to $\mathrm{COOH}$ terminal, these are Walker $\mathbf{A}(\mathrm{P}-$ loop), the family-specific ABC signature (LSGGQ) motif (also called C-loop), the

Walker B motif, and a conserved His (His-switch). The lysine residue in the Walker A motif is involved in the binding of the B-phosphate of ATP while the aspartic acid residue in the Walker B motif interacts with $\mathrm{Mg}^{2+}$ (56). The $\mathrm{ABC}$ signature motif is diagnostic for the family as it is present only in $\mathrm{ABC}$ proteins, and its facilitates the formation of the nucleotide sandwich dimmer (57-59). Finally, the Ser residue in each of the ABC signature sequence motifs appears necessary for the interaction between the Walker $\mathrm{A}$ and $\mathrm{ABC}$ signature sequences and potentially interacts with the $\gamma$-phosphate of ATP (57).

Mechanisms of drug efflux. The mechanism by which P-gp and other ABC transporters

Figure 6. (ref: 50)

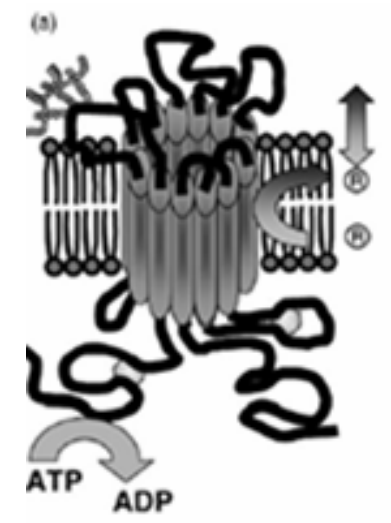

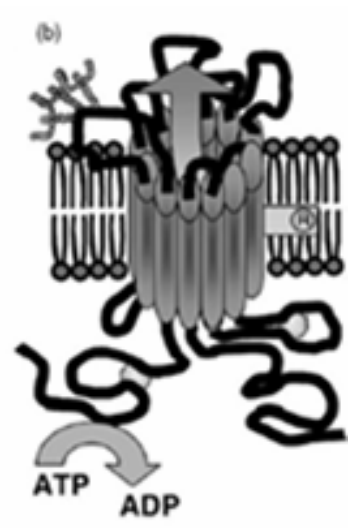
couple the hydrolysis of ATP to movement of drug across the plasma membrane is not welldefined (60). Several models have been proposed to conceptualise P-gp pump function $(61,62)$, the most widely accepted being "flippase" (a) and "hydrophobic vacuum cleaner" (b) models, (Figure 6). In "lipase" model, substrates are flipped from the inner leaflet of the lipid belayed, to either the outer leaflet of the plasma membrane where they diffuse into the extracellular region (63). A"hydrophobic vacuum cleaner" extracting hydrophobic compounds embedded in inner leaflet of the plasma membrane and pumping them directly to the external aqueous medium (64). Experimentally it is difficult to distinguish between the two models $(65,66)$. Irrespective of the models proposed, efflux occurs as a consequence of ATP binding or hydrolysis and involves four distinct phases: (i) loading with drug and ATP, (ii) inducing of conformational 
changes and altered affinity of the binding sites (drug release), (iii) ATP hydrolysis/release and (iv) a return to its starting conformation (60).

\subsection{Transported substrates of $\mathrm{ABC}$ transporters}

Based on a great deal of clinical and experimental work, it has been established that $\mathrm{ABC}$ transporters recognize a very large range of drug substrates, include a large number of anticancer drugs (anthracyclines, Vinca alkaloids, epipodophyllotoxins, taxanes). Although recognized substrates are mostly hydrophobic compounds, MDR pumps are also capable to extrude a variety of amphipathic anions and cations.

P-gp (MDR1) preferentially extrudes large $(\mathrm{Mr}>400)$ hydrophobic, amphipathic molecules with a planar ring system, and often carries a positive charge at physiological $\mathrm{pH}$ (67), However, not all putative P-gp substrates fall into this category; many are uncharged at physiological $\mathrm{pH}$ (e.g., colchicine), and several uncharged cyclic and linear hydrophobic peptides and ionophores have recently been described as P-gp substrate (67) (Table 4).

Table 4. P-gp substrates included in the multidrug resistance spectrum (Ref.: 67)

\begin{tabular}{lll}
\hline $\begin{array}{c}\text { Anthracyclines } \\
\text { Doxorubicin }\end{array}$ & $\begin{array}{c}\text { Cytotoxic agents } \\
\text { Colchicine }\end{array}$ & $\begin{array}{c}\text { Steroids } \\
\text { Aldosterone }\end{array}$ \\
Vinca alkaloids & $\begin{array}{l}\text { Emetine } \\
\text { Actinomycin D }\end{array}$ & Dexamethasone \\
Vinblastine & Puromycin & Miscellaneous \\
Vincristine & Mitoxantrone & Rhodamine 123 \\
& Hoechst 33342 \\
Epipodophyllotoxins & NAc-Leu-Leu-norLeu-al & Triton X-100 \\
Etoposide & NAc-Leu-Leu-Met-al & Prenyl-Cys methyl esters \\
Teniposide & Leupeptin & Calcein acetoxymethylester \\
& Pepstatin A & \\
Taxanes & Gramicidin D & \\
Paclitaxel & Nonactin & \\
Docetaxel & Yeast $a$-factor & \\
& &
\end{tabular}

MRP1 and BCRP can transport both hydrophobic drugs and large anion compounds, e.g. drug conjugates (glutathione or glucoronide conjugates) $(68,69)$. This "promiscuous" character, and the additional overlapping substrates recognition by the three major classes of MDR ABC transporters, provide an amazing network of drug resistance capacity in cancer cells. 


\subsection{Reversal of MDR}

Numerous compounds have been shown to inhibit the drug efflux function of P-gp $(70,71)$ and therefore, reverse cellular resistance (Figure 7). Also in our laboratory, a variety of studies have been previously performed to find MDR modulators, which, in combination of anticancer drugs, increased the anticancer effect (72-75). The first attempt was undertaken by Zamora et al., and much of them simple framework is still utilized in drug development (77). Fifteen years after this investigation Wang et al. was described a new set of criteria for P-gp

Figure 7. (Ref.:76)

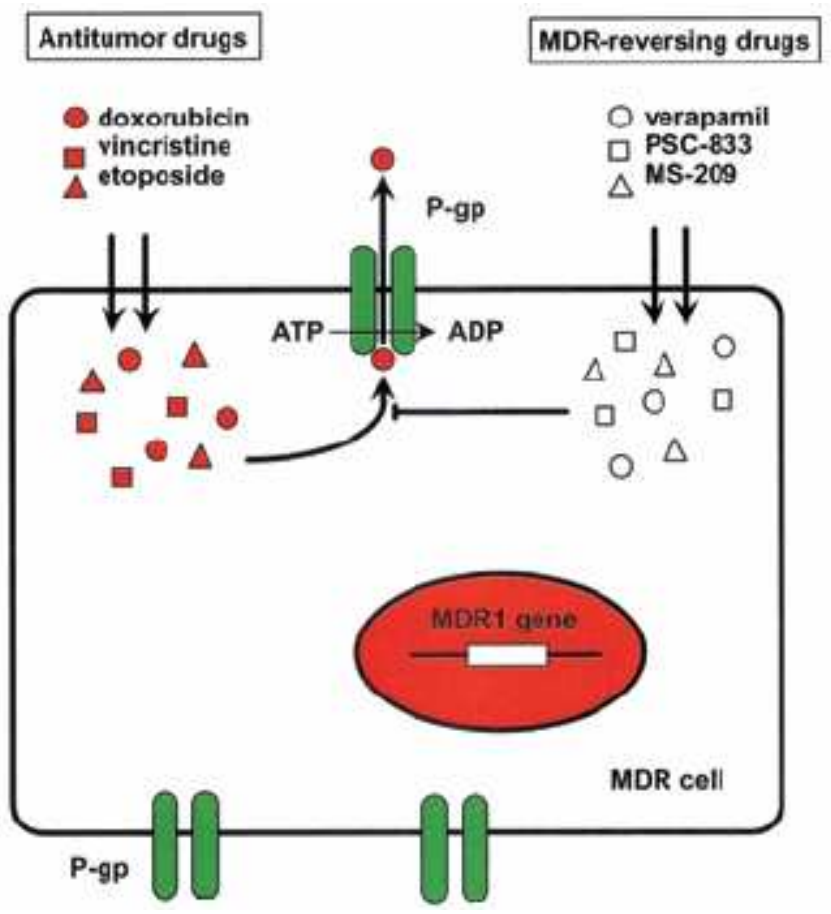
substrates (78). The criteria included (i) lipid solubility with a $\log \mathrm{P}<2.92$, (ii) a molecule size of approximately 18 atom length, (iii) nucleophilicity and (iv) at least 1 tertiary basic amine. Unfortunately, the pharmacophoric profile for P-gp inhibitors was not sufficiently stringent to facilitate drug development.

Many of the first generation chemosensitizers (e.g. verapamil (79), cyclosporine A (80), tamoxifen (81), and several calmodulin antagonists (82)) were themselves substrates for P-gp and competed with the cytotoxic drugs for efflux by the P-gp pump. Therefore, high serum concentrations of these agents were needed to produce sufficient intracellular concentration.

At these elevated doses, compounds exhibited severe and sometimes life-threatening toxicities (83). These dose-limiting toxic effects have precluded their application as effective MDR modulators for in vivo applications, particularly in the clinical practice.

The second generation modulators include either stereoisomers of their first generation racemic counterparts, such as dexverapamil (R-enantiomer of verapamil), dexniguldipine (Renantiomer of niguldipine), or structural analogs of first generation agents $(73,84-85)$, such as valspodar (PSC-833) or biricodar (VX-710), quinoline derivative (MS-209). All of these compounds exhibited decreased inherent toxicity while retaining MDR reversal efficacy compared to their parent compounds $(86,87)$, but they also retain some characteristics that limit their clinical usefulness. Many of the second generation MDR chemosensitizers are also 
substrates for cytochrom P450 3A4 and metabolized by this enzyme. The competition between cytotoxic agents and these P-gp modulators for cytochrome P450 3A4 activity has resulted in unpredictable pharmacokinetic interactions (88). Many of these MDR modulators inhibited several other ABC transporters. Inhibition of non-target transporters may enhance adverse effects of anticancer drugs (89). Side effects, due to modulation of MDR protein in normal tissues, especially blood-brain barrier should be monitored carefully to avoid neurology responses $(90,91)$.

Third generation molecules have been developed to overcome the limitations of the second generation MDR modulators. They are not metabolized by cytochrome P450 3A4 and they do not alter the plasma pharmacokinetics of anticancer drugs. Third generation agents specifically and potently inhibit P-gp and do not inhibit other ABC transporters (92). These agents exhibit effective reversing at concentrations in the nanomolar range (20-100 nM), thus requiring low doses to achieve effective MDR reversal in vivo. Examples include specific Pgp blockers such as anthranilamide derivative tariquidar (XR9576) (93), laniquidar (R101933) (94) and the substituted diarylimidazole OC144-093 (95), the cyclopropyl-dibenzosuberane zosuquidar (LY335979) (96). Clinical trials with these new third generation agents are ongoing with the aim for a longer survival in cancer patients. This effort continues, but none of them has found a general clinical use so far (92).

\subsection{Cancer chemoprevention; the oncomodulatory effect of human cytomegalovirus}

Human cytomegalovirus (CMV) is a $\beta$-herpes virus that persistently infects $50 \%$ to $90 \%$ of the adult population. Studies indicated the CMV infection might be associated with the pathogenesis of several human malignancies (97-99). A high frequency of CMV genome and antigens in tumour samples of patients with different malignancies such as Epstein-Barr virus (EBV) negative Hodgkin's disease, colon cancer, and malignant neuroblastoma, is well documented (98-99).

CMV infection can modulate multiple cellular regulatory and signalling pathways in a manner similar to that of oncoproteins of small DNA tumour viruses such as human papilloma virus or adenoviruses (100). However, in contrast to these DNA tumour viruses, CMV infections fail to transform susceptible normal human cells. CMV infection modulates properties of tumour cells such as growth, apoptosis, production of angiogenic factors, cell invasion and immunogenic properties (101). Inhibition of virus production through treatment of CMVinfected tumour cells with the antiviral agent, ganciclovir, restored the sensitivity to chemotherapy, lowered Bcl-2 expression, and facilitated sensitivity of apoptosis (Figure 8). 
Figure 8. Tumour progression induced by CMV infections (Ref.: 102)

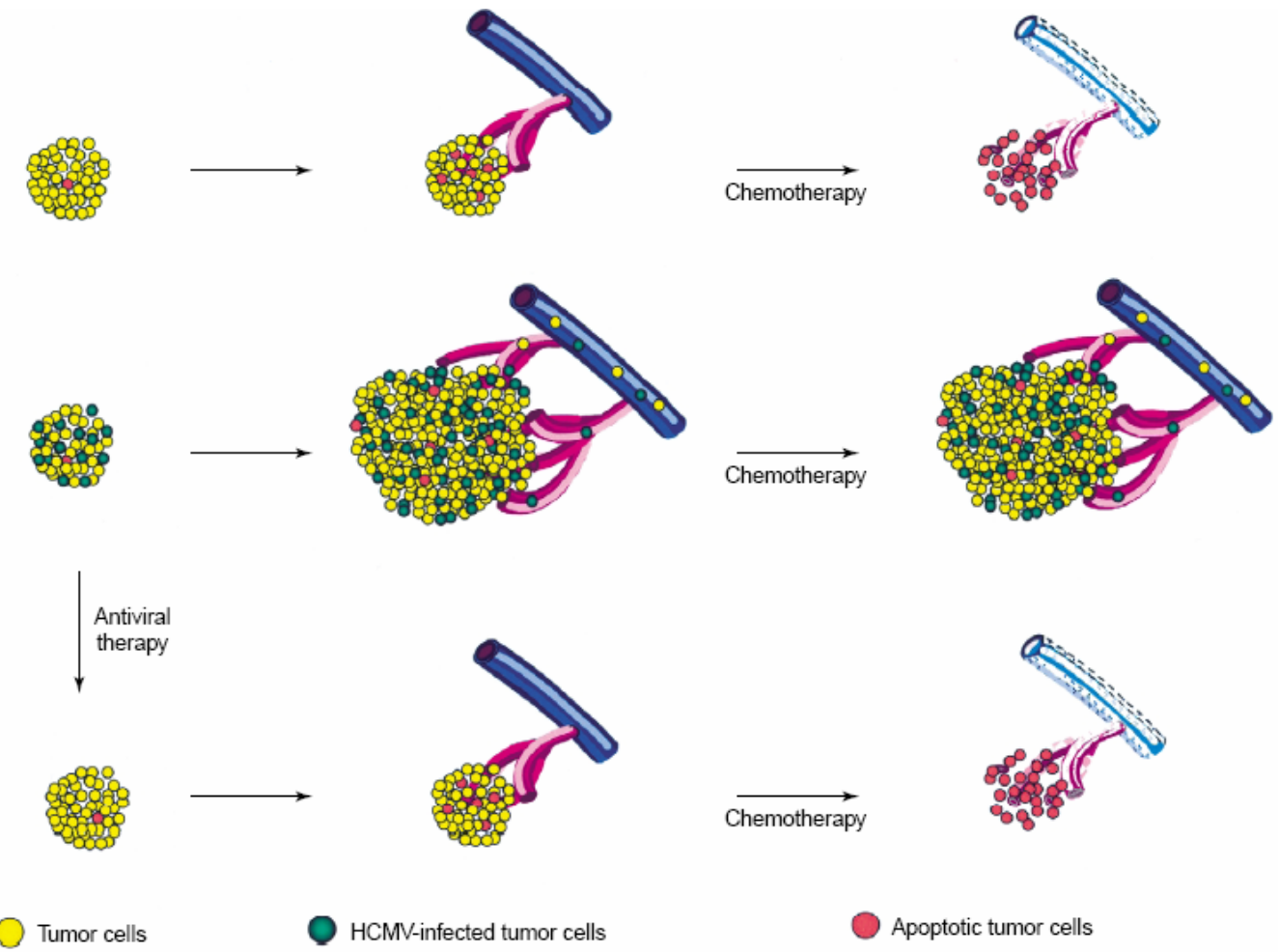

The oncomodulatory effects are mediated mainly by the activity of CMV regulatory proteins and rely on the persistence of viral infection in malignant cells. The sequential expression of the CMV genome has been divided into three phases: immediate early (IE), early (E) and late (L) antigen based on the appearance of the respective mRNA or protein (100). Both latent infection and reactivation are determined by the activity of IE gene products. IE gene products accumulate in infected cells causing disturbance of host cell functions.

The development of strategies to inhibit human CMV IE antigen expression and/or function is an important goal to prevent and treat certain forms of cancers associated with human CMV. 


\section{AIMS OF THE STUDY}

In the past few years, different studies have been performed with the aim of developing effective chemosensitizers to overcome the multidrug resistance of human cancer cells. In spite of the great number of MDR modulators known, no effective inhibitor without side effects is still available for clinical practice.

Our purpose was to find MDR reversal agents less toxic than verapamil among various synthetic compounds: cinnamylidene ketones; 1,4-dihydropyridines; phenothiazines; HSP90 inhibitor peptides; betti base derivative of tylosin and some naturally occurring plant derived jatrophane and lathyrane-type diterpenes.

The effect of selected MDR reversal compounds were studied in combination with anticancer chemotherapeutics both in vitro and in vivo. Apoptosis induction and inhibition of tumour promotion were studied as well.

Main goals of the study in details:

\section{Antiproliferative and cytotoxic effect of tested compounds}

Before starting, the multidrug resistance studies the antiproliferative and cytotoxic properties of the compounds were determined and compared on various cell lines

\section{Reversal of MDR1 by flow-cytometric assay}

1. Reversal of multidrug resistance on human $m d r l$ gene-transfected mouse lymphoma cell line (L $5178 \mathrm{Y}$ ) by various compounds (cinnamylidene ketones, 1,4-diphenyl-1,4dihydropyridines, phenothiazines, HSP90 inhibitor peptide derivatives and Betti base of tylosin derivative)

2. MDR1 reversal effect of cinnamylidene ketones, 1,4-diphenyl-1,4-dihydropyridines, phenothiazines and certain Euphorbia diterpenes on human colon cancer cells (COLO 320)

\section{Interaction of resistance modifiers with anticancer drugs}

1. Antiproliferative effect of the combination of some representative resistance modifiers and some group representative anticancer drugs (doxorubicin, epirubicin, paclitaxel, vincristine) were examined by checkerboard microplate method in vitro

2. To investigate the in vivo P-glycoprotein inhibition of the most effective MDRreversal Betti base of Tylosin derivative, N-tylosil aminonaphtol (TBN), DBA/2 mice were used bearing syngenic resistance T-cell lymphoma L $5178 \mathrm{Y}$. The doxorubicin 
accumulation in tumour in the presence or absence of modulator was compared with in vitro results

\section{Apoptosis induction of some resistance modifiers}

1. As an alternative means of cytotoxic effects, programmed cell death induction was studied of the most effective resistance modifiers: two cinnamylidene derivatives, two dihydropyridines and one Euphorbia jatrophane diterpene by flow cytometry using human $m d r l$ gene-transfected mouse lymphoma cells

2. Analysis of apoptotic events by staining with ethidium bromide and acridine orange, on human cervical adenocarcinoma cell line (HeLa) was also examined in the presence of one representative jatrophane diterpene

\section{Anti-promotion effect of plant derivatives}

To search for antitumour promoters from plants sources, the effect of some macrocyclic lathyrane-type diterpenoids, were studied on the expression of human cytomegalovirus immediate-early (IE) antigen in human lung cancer cells (A549) 


\section{MATERIALS AND METHODS}

\section{Chemicals}

Synthetic compounds

- Cinnamylidene derivatives (See Appendix 1.)

- 1,4-Diphenyl-1,4- dihydropyridine derivatives (See Appendix 2.)

- Phenothiazine derivatives: Perphenazine (Bracco-Italy), promethazine hydrochloride (EGYT-Hungary), oxomemazine (Rhone-Poulence-France), methotrimeprazine maleate (EGYTE-Hungary), trifluoropromazine hydrochloride (Squibb-England), trimeprazine (Rhone-Poulence-France), prochlorperazine dimaleate (Farmitalia) (See Appendix 3.)

- Heat Shock Protein 90 (HSP90) inhibitor peptide derivatives: $D$-Trp-Phe- $D$ Trp-Leu-AMB (1), $p$-HOPA- $D$-Trp-Phe- $D$-Trp-Leu- $\psi\left(\mathrm{CH}_{2} \mathrm{NH}\right)-\mathrm{Leu}_{-} \mathrm{NH}_{2}(2), D$ Trp-Phe- $D$-Trp-OH (3), Suc- $D$-Trp-Phe- $D$-Trp-Leu-AMB (4), $D$-Tyr-Phe- $D$-TrpLeu-AMB (5), $D$-Arg- $D$-Trp-Phe- $D$-Trp-Leu-Leu- $\mathrm{NH}_{2}$ (6), Leu- $\psi\left(\mathrm{CH}_{2} \mathrm{NH}\right)$-Leu$\mathrm{NH}_{2} \times 2 \mathrm{HCl}$ (7), Phe-Trp-Phe-Trp-Leu-Leu-NH $\mathrm{NH}_{2}$ (8), Tyr-Trp-Phe-Trp-Leu-Leu$\mathrm{NH}_{2}$ (9) and Tyr- $D$-Trp-Phe- $D$-Trp-Leu-Leu- $\mathrm{NH}_{2}(\mathbf{1 0})$

- Betti-base derivative of tylosin (TBN) (103) (See Appendix 4.)

Natural compounds

- Euphorbiaceae diterpenes: The compounds were isolated from the lipophilic phase of methanol extracts of Euphorbia esula (compounds 1, 2 and 3), E. peplus (compounds 4 and 5), E. villosa (compound 6) and E. serrulata (compound 7, 8 and 9) (See Appendix 5.)

- Macrocyclic lathyrane-type diterpenes: Compounds were isolated from the methanol extract of Euphorbia lagascae (See Appendix 6.)

Other chemicals were used in in vitro assays:

Verapamil (EGIS, Hungarian Pharmaceutical Company, Budapest, Hungary); phosphatebuffered saline and dimethyl sulfoxide (PBS and DMSO; Sigma-Aldrich Ltd., Budapest, Hungary); 3-(4,5-dimethylthiazol-2-yl)-2,5-diphenyltetrazolium bromide, sodium dodecyl sulphate and Rhodamin 123 (MTT, SDS and R123; Sigma, St Louis, MO, USA); Doxorubicin hydrochloride (Wako Pure Chem, Ind, Osaka, Japan); epirubicin hydrochloride (Farmitalia Carlo Erba, Milano, Italy);

Annexin-V-FITC (Annexin-V; human recombinant-FITC; Alexis Biochemical, Grünberg, Germany); propidium iodide and ethidium bromide/acridine orange (PI and EB/AO; Sigma-Aldrich Ltd., Budapest, Hungary);

Monoclonal antibody (MAB810; Chemicon International Inc., Temecula, CA, USA); fluorescein isothiocyanate (FITC)-conjugated rabbit anti-mouse IgG (Sigma-Aldrich Ltd., Budapest, Hungary);

The following compounds were used in in vivo assays:

Natrium-pentobarbital (Nembutal, Cave-Sante Animale, Brussels); Doxorubicin $\mathrm{HCl}$ and daunorubicin $\mathrm{HCl}$ were purchased as a powder for injection from Teva Pharma (Wilrijk, Belgium) and Aventis Pharma (Brussels, Belgium); water was purified by the Milli-Q 
system (Millipore, Milford, USA) and acidified water was prepared by the addition of perchloric acid Sigma-Aldrich (Steinheim, Germany);

\subsection{Cell cultures}

3.2.1 The L 5178 Y mouse T-cell lymphoma cells (obtained from Prof. Gottesmann, $\mathrm{NCI}$ and FDA, USA) were transfected with $\mathrm{pHa}$ MDR1/A retrovirus, as previously described (106). MDR1-expressing cell lines were selected by culturing the infected cells with $60 \mathrm{ng} / \mathrm{mL}$ colchicine to maintain the expression of the MDR phenotype. The parent L5178 Y (PAR) mouse T-cell lymphoma cells and the transfected subline (MDR) were cultured in McCoy's 5A medium supplemented with 10\% heat-inactivated horse serum (HS; Gibco, Auckland, New Zealand) Lglutamine and antibiotics.

3.2.2 The human colon cancer cells (COLO 320) were cultured in RPMI 1640 medium (Gibco BRL, Gland Island, NY, USA) supplemented with $10 \%$ heat-inactivated fetal bovine serum (FBS; JRH Biosci, Lenexa, KS, USA), 2 mM L-glutamine, 1 $\mathrm{mM}$ Na-pyruvate and $100 \mathrm{mM}$ Hepes.

3.2.3 The human cervical adenocarcinoma cells (HeLa) were cultivated in Eagle's MEM (Gibco BRL, Paisley, UK) supplemented with 10\% heat-inactivated FBS, $1 \%$ non-essential amino acids and an antibiotic-antimycotic mixture.

3.2.4 The human lung alveolar epithelial cells (A549) were cultivated in Eagle's MEM supplemented with 10\% fetal calf serum (FCS) and for immunofluorescence studies cells were grown on glass coverslips in 24 well plates containing $2 \times 10^{5}$ cells/ well.

3.2.5 Normal human lung fibroblast (MRC 5) were cultivated in Eagle's MEM supplemented with $2 \mathrm{mM}$ L-glutamine, $0.1 \mathrm{mM}$ non-essential amino acids, $10 \%$ FBS supplemented with antibiotics

The cell lines were incubated in a humified atmosphere $\left(5 \% \mathrm{CO}_{2}, 95 \%\right.$ air $)$ at $37{ }^{\circ} \mathrm{C}$. The semiadherent human cancer cells were detached with $0.25 \%$ trypsin and $0.02 \%$ EDTA for 5 $\min$ at $37^{\circ} \mathrm{C}$.

\subsection{Animals}

DBA/2 inbred mice (female, 5-7 weeks old) were obtained from Charles River Laboratory (France). After an experiment, the animals were killed by cervical dislocation. All aspects of the animal experiment and husbandry were carried out in compliance with national and European regulations and were approved by the Animal Care and Use Committee of K. U. Leuven.

\subsection{Virus}

The stock of human CMV laboratory-adapted strain "Towne" was propagated in confluent MRC-5 cells grown in RPMI medium supplemented with 10\% FCS and antibiotics. The infectivity titer was determined by plaque assay with the inoculation of confluent MRC 5 in 24 well plates.

\subsection{Assay for antiproliferative and cytotoxic effect}

The effects of increasing concentrations of the drugs alone on cell growth were tested in 96well flat-bottomed microtiter plates as described in Publication I and V. 
(In case of cytotoxicity test, the cell number was higher $\left(3 \times 10^{4} /\right.$ well) and the incubation time was only $48 \mathrm{~h}$.) The cell growth was determined by measuring the optical density (OD) at 550 $\mathrm{nm}$ (ref. $630 \mathrm{~nm}$ ) with a Dynatech MRX vertical beam ELISA reader (Labsystems, Helsinki, Finland). Inhibition of cell growth (as a percentage) was determined according to the formula:

$$
100-\left[\frac{\text { OD sample-OD medium control }}{\text { ODcell control-OD medium control }}\right] \times 100
$$

\subsection{Flow-cytometric assay for R123 accumulation in tumour cells}

Reversal of MDR was examined by using a standard functional assay with R123. The fluorescence of the cell population was measured by flow cytometry using a Beckton Dickinson FACScan instrument (cell sorter, Oxford, U.K.) as described previously (Publication I, II and Ref.:74).

The fluorescence of activity ratio (FAR) was calculated (107), based on the measured fluorescence intensities (FL1):

$$
F A R=\frac{\text { FL1 treated cells }}{\text { FL1 untreated cells }}
$$

The results are one representative experiment of flow cytometry in which 10000 individual cells were investigated, because experiments cannot be repeated exactly.

\subsection{Checkerboard microplate methods as a model for combination therapy}

It was applied to study the effects of drug interactions between resistance modifiers and cytotoxic compound on cancer cells.

The effects of the anticancer drug and the resistance modifiers in combination were studied on various cancer cell lines (see Publication I, IV, VI and Ref.: 75). The cell growth rate was determined after MTT staining and the intensity of the blue colour was measured on a micro ELISA reader. Drug interactions were evaluated according to the following expressions:
$\mathrm{FIC}_{\mathrm{A}}=\mathrm{ID}_{50 \mathrm{~A} \text { in combination }} / \mathrm{ID}_{50 \mathrm{~A} \text { alone }}$
(Equation 3)
$\mathrm{FIC}_{\mathrm{B}}=\mathrm{ID}_{50 \mathrm{~B} \text { in combination }} / \mathrm{ID}_{50 \mathrm{~B} \text { alone }}$
(Equation 4)

where ID is the inhibitory dose, and FIC is the fractional inhibitory concentration.

The fractional inhibitory index, FIX $=\mathrm{FIC}_{\mathrm{A}}+\mathrm{FIC}_{\mathrm{B}}$, demonstrates the effect of the combination of the anticancer drug and the tested compound. It is accepted that, if the value of FIX is $0.51-1.00$, it is an additive effect; if FIX is $<0.50$, it is a synergistic one; a FIX value in the interval 1.00-2.00 is considered an indifferent effect, while a value $>2.00$ indicates an antagonistic effect (108).

\subsection{Cellular accumulation and cytotoxicity of doxorubicin in vitro}

Parental or transfected L5178 Y cells were plated using 24 well plates $\left(4 \times 10^{6}\right.$ cell $/ 1.5 \mathrm{ml}$ per well) in serum-free medium. TBN $(10 \mu \mathrm{M})$ was added (or not) $30 \mathrm{~min}$ before exposing the cells to $40 \mu \mathrm{M}$ doxorubicin at $37^{\circ} \mathrm{C}$ for $1 \mathrm{~h}$. The cell suspensions were centrifuged on 4500 rpm for $5 \mathrm{~min}$ and washed twice with ice-cold PBS. After resuspending the cells in water, doxorubicin was extracted (using $60 \%$ ethanol $+0.3 \mathrm{M} \mathrm{HCl}$ ) and quantified by high performance liquid chromatography (HPLC). For the toxicity assay, the cell suspensions were also centrifuged on $4500 \mathrm{rpm}$ for $5 \mathrm{~min}$ and washed twice in serum-free medium. The cells were cultured for $48 \mathrm{~h}$ at $37{ }^{\circ} \mathrm{C}$ using 96 well plates $\left(10^{5}\right.$ cell $/ 0.15 \mathrm{ml}$ per well $)$ in serum 
supplemented medium. Cell proliferation was evaluated by the above mentioned MTT test. Statistical analysis was performed by using an ANOVA model.

\subsection{In vivo studies}

\subsubsection{In vivo doxorubicin accumulation}

$\mathrm{DBA} / 2$ mice were anesthetized and injected subcutaneously with $4 \times 10^{6}$ cells of the parental or transfected L $5178 \mathrm{Y}$ cells. Tumours were allowed to grow to ca $0.5 \mathrm{~cm}$ diameter, after which the animals were treated once with various regimens of TBN $(10$ and $50 \mathrm{mg} / \mathrm{kg})$ or vehicle, and doxorubicin $(10 \mathrm{mg} / \mathrm{kg})$ or vehicle, administered either i.p. or i.v. via a lateral tail vein. Tumours were excised $24 \mathrm{~h}$ after i.p. or i.v. administration and stored at $-20^{\circ} \mathrm{C}$ until extraction and HPLC analysis.

\subsubsection{Sample extraction and doxorubicin quantification}

The amount of doxorubicin in frozen tumour quantified as described by Asperen et al. (109). Samples were thawed and thoroughly homogenized. Dilutions of the homogenate were prepared in water $(100 \mathrm{mg} / \mathrm{mL})$, and $200 \mu \mathrm{L}$ aliquots were diluted with an equal volume of $6 \%(\mathrm{w} / \mathrm{v})$ borate buffer ( $\mathrm{pH} 9.5)$ and $50 \mu \mathrm{L}$ internal standard (daunorubicin) working solution. After vortexing, the analytes were extracted with $1 \mathrm{~mL}$ of a chloroform/propanol mixture $(4: 1$, $\mathrm{v} / \mathrm{v})$ by mixing for $5 \mathrm{~min}$, followed by centrifugation for $10 \mathrm{~min}$ at $4^{\circ} \mathrm{C}(6000 \mathrm{rpm})$. The aqueous layer and the pellet were removed by suction, and the isolated organic layer evaporated using a Speed-Vacuum system (Reciprotor, Denmark) at $43^{\circ} \mathrm{C}$. The residue was reconstituted in $75 \mu \mathrm{L}$ of acetonitrile-tetrahydrofuran $(40: 1, \mathrm{v} / \mathrm{v})$, vortexed for $20 \mathrm{~s}$ and then sonicated for $5 \mathrm{~min}$. After adding $125 \mu \mathrm{L}$ acidified water ( $\mathrm{pH} 2.05)$, a $20 \mu \mathrm{L}$ aliquot was analyzed by LC. The LC system consisted of a Hitachi Elite LaChrom L-2130 solvent delivery module and a Hitachi Elite LaChrom L-2480 fluorescence detector (Hitachi HighTechnologies Corporation Tokyo, Japan). The LiChroCART 250-4 analytical column packed with $5 \mu \mathrm{m}$ Purospher STAR material (Merck, Darmstadt, Germany) was protected by a LiChrospher guard column $(4 \times 4 \mathrm{~mm})$ (Merck, Darmstadt, Germany). The mobile phase was composed of acidified water ( $\mathrm{pH} 2.05) /$ acetonitrile/THF $(64: 35: 1, \mathrm{v} / \mathrm{v} / \mathrm{v})$ and was degassed by ultrasonication. A flow rate of $0.8 \mathrm{ml} / \mathrm{min}$ was used. The column eluent was monitored fluorimetrically at $460 \mathrm{~nm}(\mathrm{ex})$ and $550 \mathrm{~nm}(\mathrm{em})$.

Statistical analysis. Statistical analysis of the data was performed with Graphpad Prism 2.01 (Graph Pad Software, San Diego, CA, USA).

\subsection{Apoptosis assays}

\subsubsection{Flow-cytometric assay for apoptosis}

The cells were adjusted to a density of $2 \times 10^{5} / \mathrm{mL}$ and were distributed in $1.0 \mathrm{~mL}$ aliquots into microcentrifuge tubes. The apoptosis inducer $12 H$-benzo[ $\alpha]$ phenothiazine (M627) was added to the samples as a positive control at a final concentration of 5 or $25 \mu \mathrm{g} / \mathrm{mL}$. The M627 was synthesized by Motohashi et al. (110). In the cases of control cultures, $10 \mu \mathrm{L}$ DMSO was added. The compounds used for treatment was added to the samples at a final concentration of 2 or $10 \mu \mathrm{g} / \mathrm{mL}$. After incubation for $24 \mathrm{~h}$ at $37^{\circ} \mathrm{C}$, the cells were transferred from a 24-well plate into Eppendorf centrifuge tubes, centrifuged and washed with PBS, and resuspended in $195 \mu \mathrm{L}$ binding buffer. The samples were mixed, centrifuged and supernatant was removed from each tube. $5 \mu \mathrm{L}$ Annexin $\mathrm{V}$ was added to the tubes. Controls without Annexin V were 
also prepared. The samples and controls were incubated at room temperature for $10 \mathrm{~min}$ in the dark, then centrifuged, washed with PBS, and resuspended in $190 \mu \mathrm{L}$ binding buffer. Before the measurement of fluorescence activity, $10 \mu \mathrm{L}$ of $20 \mu \mathrm{g} / \mathrm{mL}$ PI was added to the samples and the apoptosis of the cells was investigated. The fluorescence activity (FL-1 and FL-2) of the cells was measured and analysed on a Beckton Dickinson FACScan instrument. In each analysis, 10000 events were recorded, and the percentages of the cells in the different states were calculated by using winMDI2.8 (111).

3.10.2 Ethidium bromide and acridine orange (EB/AO) staining for apoptosis Staining with EB/AO was carried out in a 96-well plate format after $24 \mathrm{~h}$ of treatment in order to visualize the basic morphological events (112). Plates were centrifuged at $1000 \mathrm{rpm}$ for 5 min, and $8 \mu \mathrm{L}$ of staining solution $(0.1 \mathrm{mg} / \mathrm{mL}$ for both AO and EB in PBS) was added to each well. After $10 \mathrm{~min}$, the cells were washed with PBS, and the cells were viewed with a Nikon Eclipse inverted microscope at 200x magnification with a 500/20 nm excitation filter, a cut-on $515 \mathrm{~nm}$ LP dichromatic mirror, and a $520 \mathrm{~nm}$ LP barrier filter (Chroma Technology, Rockingham, VT, USA). Pictures were taken with a Nikon Coopix 4500 digital camera (Nikon, Tokyo, Japan).

\subsection{Anti-promotion experiments}

One-day-old A549 cultures on the coverslips were infected with the "Towne" strain of CMV as described previously (Publication V). Human CMV IE1-72 antigen was detected in the nuclei of infected cells by immunostaining using monoclonal antibody (MAB810) and FITCconjugated rabbit anti-mouse IgG. The number of IE antigen-positive cells was counted in 30 microscopic fields containing 400 cells for each sample. The frequency of IE antigenexpressing cells in the treated cultures is shown as a percentage of the control. 


\section{RESULTS}

\subsection{Antiproliferative and cytotoxic effect of tested compounds}

In the first stage of study, the antiproliferative and toxic property of various compounds were determined of possible MDR modifiers. The inhibitory dose fifty $\left(\operatorname{ID}_{50}\right)$ values were studied in each examined compounds by MTT test.

Considering the large number of studied compounds, only some representative chemicals are shown in the table below.

As shown in Table 1, there are some interesting compounds, e.g.: cinnamylidene 1, 2, 4, and 10, which had higher $\mathrm{ID}_{50}$ values for the MDR cells than for the PAR cell line. It is possible that these compounds are substrates of the P-gp-mediated efflux pump. COLO 320 has a moderate sensitivity for the antiproliferative effects of the cinnamylidene ketones.

\section{Table 1. Comparison of the antiproliferative effects of cinnamylidene ketones on PAR, MDR and COLO 320 cell lines}

\begin{tabular}{|c|c|c|c|}
\hline \multirow[t]{2}{*}{ Compounds } & \multicolumn{3}{|c|}{ ID $_{50}$ values $(\mu \mathrm{g} / \mathrm{mL}) \pm$ S.E.M ${ }^{*}$} \\
\hline & L 5178 Y MDR & L 5178 Y PAR & COLO 320 \\
\hline 1 & $98.99 \pm 0.89$ & $60.00 \pm 0.99$ & $10.83 \pm 0.39$ \\
\hline 2 & $43.75 \pm 0.65$ & $41.04 \pm 0.44$ & $6.00 \pm 0.11$ \\
\hline 3 & $3.31 \pm 0.12$ & $11.76 \pm 0.12$ & $0.75 \pm 0.02$ \\
\hline 4 & $49.00 \pm 0.55$ & $25.89 \pm 0.88$ & $16.80 \pm 0.19$ \\
\hline 5 & $9.97 \pm 0.05$ & $20.18 \pm 0.15$ & $5.05 \pm 0.78$ \\
\hline 6 & $2.31 \pm 0.03$ & $65.34 \pm 0.34$ & $8.72 \pm 0.67$ \\
\hline 7 & $15.21 \pm 0.19$ & $89.35 \pm 0.98$ & $7.05 \pm 0.03$ \\
\hline 8 & $37.26 \pm 0.39$ & $72.87 \pm 0.23$ & $8.58 \pm 0.93$ \\
\hline 9 & $9.91 \pm 0.34$ & $22.23 \pm 0.03$ & $6.36 \pm 0.77$ \\
\hline 10 & $51.76 \pm 0.99$ & $46.87 \pm 0.56$ & $8.94 \pm 0.56$ \\
\hline 11 & $3.99 \pm 0.78$ & $67.44 \pm 0.42$ & $4.58 \pm 0.88$ \\
\hline 12 & $12.68 \pm 0.11$ & $33.31 \pm 0.30$ & $9.36 \pm 0.93$ \\
\hline 13 & $52.35 \pm 0.02$ & $62.53 \pm 0.74$ & $13.22 \pm 0.16$ \\
\hline 14 & $4.88 \pm 0.44$ & $13.51 \pm 0.12$ & $0.68 \pm 0.09$ \\
\hline 15 & $15.17 \pm 0.22$ & $65.00 \pm 0.94$ & $3.11 \pm 0.07$ \\
\hline 16 & $17.34 \pm 0.98$ & $70.00 \pm 0.22$ & $17.02 \pm 0.85$ \\
\hline DMSO & $23.50 \pm 0.50$ & $52.50 \pm 0.11$ & $11.34 \pm 0.46$ \\
\hline
\end{tabular}

*All values are expressed as mean \pm S.E.M (standard errors of mean) from parallel experiments $(n=2-4)$

The cytotoxicity of dihydropyridines was also examined by using seven human cell lines (Publication II). The results confirmed the tumour specificity of some compounds. The dihydropyridine derivatives were more cytotoxic against four oral tumour cell lines as 
compared with normal cells. However, the tumour cell lines display considerable variation in sensitivity. On the other hand, the normal cells were all comparable in sensitivity.

Plants of the genus Euphorbia are known to produce a large variety of diterpenoids; some of them display tumour-promoting activity, while others exhibit cytostatic activity (113). In order to prepare the long-term combination experiments, the antiproliferative effect of several new jatrophane diterpene polyesters were tested on COLO 320 cell line. The similar effect on human $m d r l$ gene-transfected mouse lymphoma cell line was earlier studied $(114,115)$. The applied chemotherapeutic, epirubicin reduced the proliferation of COLO 320 cell line ( $\left.\mathrm{ID}_{50}=0.10 \pm 0.03\right)$; a majority of the compounds exhibited a moderate antiproliferative effect. ID $_{50}$ values of most of diterpene derivatives are similar (between 5 and 17).

The cytotoxicity of macrocyclic lathyrane diterpenes on the human lung cancer (A549) and on the normal human lung fibroblast (MRC 5) was measured (Table 2). In order to assess the preferential toxicity for malignant cells, tumour specificity (TS) was calculated for each compounds. The TS values indicated that Latilagalascene $\mathbf{C}$ and Jolkinol $\mathbf{B}$ had the most noteworthy tumour-specific cytotoxic action. The cancer cells were apparently more sensitive than the MRC5 cell line to the selected diterpenes.

\begin{tabular}{|l|c|c|c|}
\hline \multicolumn{4}{|c|}{ Table 2. Cytotoxic effects of lathyrane-type diterpenes on A549 lung cancer cell line } \\
and on MRC 5 normal lung fibroblasts
\end{tabular}

${ }^{*} \mathrm{TS}=\mathrm{ID}_{50}$ (normal) / $\mathrm{ID}_{50}$ (tumour)

This complex effect on cell proliferation and viability may depend on the chemical structure of each derivatives and sensitivity of cell lines.

\subsection{Reversal of MDR1 by flow-cytometric assay}

The standard assay to evaluate the potency of various compounds as MDR modulators is based on the increased accumulation of Rhodamin 123 in MDR and sensitive cells. 


\subsubsection{Reversal of multidrug resistance on human mdr1 gene-transfected mouse lymphoma cell line (L 5178 Y)}

\section{2. 1. 1 Cinnamylidene ketones}

Some of the cinnamylidene derivatives were able to enhance the drug accumulation of MDR cells markedly: 1, 2, 4, 7, 8, 10 and 11 (Table 3). The compounds displayed dose-dependent inhibition of the MDR P-gp. At the same time, certain cinnamylidene derivatives $(\mathbf{5}, \mathbf{6}, \mathbf{9}, 13$ and 16) were hardly effective in inhibiting the naturally occurring MDR of the mouse lymphoma cells. The FAR value of reference compound, verapamil was 4.235 in $10 \mu \mathrm{g} / \mathrm{mL}$ concentration.

\begin{tabular}{|l|c|c|}
\hline \multicolumn{3}{|c|}{ Table 3. The effects of cinnamylidene derivatives on R123 accumulation on $\mathbf{L} \mathbf{5 1 7 8} \mathbf{~ Y}$} \\
cell line \\
\hline \multirow{2}{*}{ Samples } & FAR values at various concentration \\
\cline { 2 - 3 } & $\mathbf{4} \mathbf{\mu g} / \mathbf{m L}$ & $\mathbf{4 0} \boldsymbol{\mu g} / \mathbf{m L}$ \\
\hline $\mathbf{1}$ & 1.60 & 18.94 \\
\hline $\mathbf{2}$ & 1.32 & 23.61 \\
\hline $\mathbf{3}$ & 2.66 & 14.60 \\
\hline $\mathbf{4}$ & 4.19 & 32.73 \\
\hline $\mathbf{5}$ & 1.90 & 2.97 \\
\hline $\mathbf{6}$ & 1.13 & 2.05 \\
\hline $\mathbf{7}$ & 3.09 & 26.17 \\
\hline $\mathbf{8}$ & 8.32 & 61.30 \\
\hline $\mathbf{9}$ & 1.16 & 1.60 \\
\hline $\mathbf{1 0}$ & 3.28 & 27.34 \\
\hline $\mathbf{1 1}$ & 10.53 & 19.86 \\
\hline $\mathbf{1 2}$ & 6.52 & 12.34 \\
\hline $\mathbf{1 3}$ & 1.09 & 2.33 \\
\hline $\mathbf{1 4}$ & 1.82 & 7.73 \\
\hline $\mathbf{1 5}$ & 8.50 & 13.51 \\
\hline $\mathbf{1 6}$ & 2.09 & 2.18 \\
\hline
\end{tabular}

\section{2. 1 Dihydropyridine derivatives}

The effects of the forty-one substituted 1,4-diphenyl-1,4-dihydropyridine derivatives on MDR reversal were investigated by treating the mouse lymphoma L 5178 Y cells transfected with the human $m d r l$ gene. Certain dihydropyridines at the higher concentration of $40 \mu \mathrm{g} / \mathrm{mL}$ used were found to be toxic: the cell size and the intracellular structures of the cells were changed during the short-term experiments (Publication II). Then non-toxic concentration $(0.4 \mu \mathrm{g} / \mathrm{mL})$ was applied for experiments on R123 accumulation. At some representative samples, the results are presented in Table 4. Among them, DL8-10, DL12, DL13 and DL15 were found to be the most effective MDR modulator. 


\begin{tabular}{|l|c|c|c|}
\hline \multicolumn{4}{|c|}{$\begin{array}{c}\text { Table 4. The effects of 1,4-diphenyl-1,4-dihydropyridine derivatives on R123 } \\
\text { accumulation on L } \mathbf{5 1 7 8} \text { Y cell line }\end{array}$} \\
\hline \multirow{2}{*}{ Samples } & $\mathbf{3}$ & FAR values at various concentration \\
\cline { 2 - 4 } & $\mathbf{0 . 4} \boldsymbol{\mu g}$ /mL & $\mathbf{4} \boldsymbol{\mu g} / \mathbf{m L}$ & $\mathbf{4 0} \boldsymbol{\mu g} / \mathbf{m L}$ \\
\hline DL1 & 9.53 & 24.50 & 12.09 \\
\hline DL2 & 11.01 & 47.34 & 33.88 \\
\hline DL3 & 20.80 & 49.81 & 30.27 \\
\hline DL4 & 16.43 & 45.51 & 28.70 \\
\hline DL5 & 5.33 & 20.22 & 10.31 \\
\hline DL8 & 10.00 & 115.67 & 178.03 \\
\hline DL9 & $*$ & 54.49 & 104.58 \\
\hline DL10 & $*$ & 4.99 & 139.61 \\
\hline DL12 & $*$ & 7.50 & 77.03 \\
\hline DL13 & 5.69 & 12.64 & 91.07 \\
\hline DL15 & 5.09 & 144.00 & 158.00 \\
\hline DP70 & 16.93 & 40.00 & 38.89 \\
\hline DP80 & 8.03 & 41.62 & 40.91 \\
\hline DP82 & 1.07 & 52.08 & 19.73 \\
\hline DP89 & 50.14 & 8.14 \\
\hline
\end{tabular}

The FAR value of reference compound, verapamil was 12.77 in $10 \mu \mathrm{g} / \mathrm{mL}$ concentration. * the MDR reversal effect of these compounds tested only in 4 and $40 \mu \mathrm{g} / \mathrm{mL}$ concentrations

\section{2. 1. 3 Phenothiazines}

Seven phenothiazine derivatives were tested on MDR mouse lymphoma cells (Table 5).

\begin{tabular}{|l|c|c|}
\hline \multicolumn{2}{|c|}{ Table 5. The effects of phenothiazine derivatives on R123 accumulation on L 5178 Y } \\
cell line
\end{tabular}

Numbers with the superscript ${ }^{*}$ indicate cytotoxic effect induced by the particular phenothiazine derivative

At concentration of $4 \mu \mathrm{g} / \mathrm{mL}$ all phenothiazines used were moderately active, however only two of them (perphenazine and prochlorperazine dimaleate) were more powerful MDR inhibitors than verapamil $(\mathrm{FAR}=8.34$ at $10 \mu \mathrm{g} / \mathrm{mL}$ concentration). Apparently, at four concentrations used $(0.5,1,2$ and $4 \mu \mathrm{g} / \mathrm{mL})$ perphenazine and prochlorperazine dimaleate affect MDR in mouse lymphoma cells (Table 6). 


\begin{tabular}{|c|c|c|c|c|c|}
\hline \multicolumn{6}{|c|}{$\begin{array}{l}\text { Table 6. The effects of perphenazine and prochlorperazine dimaleate on R123 } \\
\text { accumulation on } \mathrm{L} 5178 \text { Y cell line }\end{array}$} \\
\hline \multirow[t]{2}{*}{ Samples } & \multicolumn{5}{|c|}{ FAR values at various concentration } \\
\hline & $0.5 \mu \mathrm{g} / \mathrm{mL}$ & $1 \mu \mathrm{g} / \mathrm{mL}$ & $2 \mu \mathrm{g} / \mathrm{mL}$ & $4 \mu \mathrm{g} / \mathrm{mL}$ & $10 \mu \mathrm{g} / \mathrm{mL}$ \\
\hline Verapamil & & & & & 12.30 \\
\hline Perphenazine & 1.73 & 5.52 & 9.00 & 12.60 & \\
\hline Prochlorperazine dimaleate & 1.44 & 7.28 & 7.97 & 9.45 & \\
\hline
\end{tabular}

Moreover, the perphenazine stimulating effect on Rhodamin 123 accumulation was stronger than that of Verapamil.

\section{2. 1. 4 HSP 90 Inhibitor Peptide derivatives}

When peptide derivatives were tested on the mouse lymphoma cells, peptide $\mathbf{1}$ and $\mathbf{4}$ displayed a dose-dependent increase in the FAR value (Table 7). The majority of antiproliferative peptide practically ineffective in MDR reversal.

\begin{tabular}{|l|c|c|}
\hline \multirow{2}{*}{ Table 7. The effects of HSP90 inhibitor peptide derivatives on R123 accumulation on } \\
L $\mathbf{5 1 7 8}$ Y cell line \\
\hline \multirow{2}{*}{ Samples } & \multicolumn{2}{|c|}{ FAR values at various concentration } \\
\cline { 2 - 3 } & $\mathbf{8} \boldsymbol{\mu \mathbf { g }} \mathbf{\text { mL }}$ & $\mathbf{4 0} \boldsymbol{\mu g} / \mathbf{m L}$ \\
\hline Peptide 1 & 12.15 & 13.00 \\
\hline Peptide 2 & 1.18 & 1.31 \\
\hline Peptide 3 & 1.10 & 0.92 \\
\hline Peptide 4 & 1.22 & 10.47 \\
\hline Peptide 5 & 1.07 & 1.03 \\
\hline Peptide 6 & 0.97 & 0.83 \\
\hline Peptide 7 & 0.89 & 0.98 \\
\hline Peptide 8 & 1.01 & 1.05 \\
\hline Peptide 9 & 1.07 & 1.41 \\
\hline Peptide 10 & 0.81 & 0.84 \\
\hline
\end{tabular}

${ }^{*}$ Verapamil (FAR $=7.85$ in $10 \mu \mathrm{g} / \mathrm{mL}$ concentration)

Compound 5 proved ineffective in inhibiting the ABC transporters, but was selected as a negative control in the flow-cytometric experiments because of its somewhat similar chemical structure to that of peptide derivative 4. Apparently, derivatives having D-Trp or DTyr residue in the $\mathrm{N}$-terminal position of the peptide were the effective compounds that mean some sequence specificity of peptide-P-gp interaction. 


\section{2. 1. 5 Betti base of Tylosin}

TBN and its two building blocks, i.e. Betti-base and tylosin, were examined in a R123 accumulation assay for their P-gp inhibitory effect, using human $m d r l$ gene transfected L 5178 Y mouse lymphoma cells. The results are shown in Table 8. TBN resulted near 100 fold higher R123 accumulation in mouse lymphoma cells than its two building blocks still at low concentration, while its precursors shown only limited effect. In these experiments, no sign of toxicity or cell damage were observed.

\begin{tabular}{|c|c|c|}
\hline \multicolumn{3}{|c|}{ Table 8. The effects of TBN and its two precursor moiety on R123 accumulation on $\mathbf{L}$} \\
$\mathbf{5 1 7 8}$ Y cell line \\
\hline \multirow{2}{*}{ Samples } & \multicolumn{2}{|c|}{ FAR values at various concentration ${ }^{*}$} \\
\cline { 2 - 3 } & $\mathbf{4} \boldsymbol{\mu g} / \mathbf{m L}$ & $\mathbf{4 0} \boldsymbol{\mu g} / \mathbf{m L}$ \\
\hline Betti base & 10 & 8 \\
\hline Tylosin & 1 & 5 \\
\hline TBN & 105 & 94 \\
\hline
\end{tabular}

FAR value of Verapamil was 10 in $10 \mu \mathrm{g} / \mathrm{mL}$ concentration

\subsubsection{MDR1 reversal effect on human colon cancer cells (COLO 320)}

\section{2. 2. 1 Cinnamylidene ketones}

When the cinnamylidene ketones were tested for the reversal of MDR in the human colon cancer cells, three groups could be distinguished, as may be see in Table 9.

\begin{tabular}{|l|c|c|}
\hline \multicolumn{3}{|c|}{ Table 9. The effects of cinnamylidene derivatives on R123 accumulation on COLO 320 } \\
cell line
\end{tabular}

"FAR value of Verapamil was 4.245 in $10 \mu \mathrm{g} / \mathrm{mL}$ concentration 
The first group contains the most effective compounds, $1,3,4,7, \mathbf{8}, \mathbf{1 0}, 11$ and 14 . The compounds in the second group, 5, 6, 9 and 12, were practically ineffective. In the third group, moderate increases in drug accumulation were found in the presence of compounds 2 , 13, 15 and 16.

\section{2. 2. 2 Dihydropyridine derivatives}

The dihydropyridines displayed lower FAR values in human colon cancer cells than in human $m d r 1$ gene-transfected mouse lymphoma cell line, with a few exceptions (such as DL12, and 13). Some representative samples revealed by Table 10 (Publication II). At higher concentration of the compounds $(40 \mu \mathrm{g} / \mathrm{mL})$, most cells died due to the toxicity of the chemicals. It was shown that most of the derivatives were able to increase the R123 accumulation without toxic effects.

\begin{tabular}{|l|c|c|c|}
\hline \multicolumn{4}{|c|}{$\begin{array}{c}\text { Table 10. The effects of 1,4-diphenyl-1,4-dihydropyridine derivatives on R123 } \\
\text { accumulation on COLO 320 cell line }\end{array}$} \\
\hline \multirow{3}{*}{ Samples } & \multicolumn{3}{|c|}{ FAR values at various concentration } \\
\cline { 2 - 4 } & $\mathbf{0 . 4} \boldsymbol{\mu g} / \mathbf{m L}$ & $\mathbf{4} \boldsymbol{\mu g} / \mathbf{m L}$ & $\mathbf{4 0} \boldsymbol{\mu g} / \mathbf{m L}$ \\
\hline DL1 & 4.26 & 12.52 & 18.32 \\
\hline DL2 & 6.33 & 21.89 & 26.08 \\
\hline DL3 & 4.13 & 27.79 & 24.51 \\
\hline DL4 & 6.69 & 23.34 & 28.36 \\
\hline DL5 & 2.57 & 14.38 & 17.81 \\
\hline DL8 & 6.59 & 60.27 & 76.13 \\
\hline DL9 & $*$ & 40.63 & 69.04 \\
\hline DL10 & $*$ & 4.69 & 140.12 \\
\hline DL12 & $*$ & 3.34 & 109.35 \\
\hline DL13 & $*$ & 18.18 & 144.09 \\
\hline DL15 & 2.5 & 44.45 & 64.82 \\
\hline DP70 & 3.56 & 33.26 & 40.33 \\
\hline DP80 & 2.55 & 36.22 & 27.80 \\
\hline DP82 & 2.14 & 31.04 & 36.73 \\
\hline DP89 & 10.73 & 36.38 & 29.37 \\
\hline
\end{tabular}

The FAR value of reference compound, Verapamil was 14.69 in $10 \mu \mathrm{g} / \mathrm{mL}$ concentration. *the MDR reversal effect of these compounds tested only in 4 and $40 \mu \mathrm{g} / \mathrm{mL}$ concentration

\section{2. 2. 3 Phenothiazines}

Some phenothiazines (perphenazine, prochlorperazine dimaleate and trifluoropromazine hydrochloride) were found to be toxic at the applied higher concentration in COLO 320 cell line, the extent that it was not able to examine the cells under the test conditions (Table 11). If 
the drug concentration was reduced obviously, it behaves as an effective MDR inhibitor and did not cause cell death (Table 12).

\begin{tabular}{|l|c|c|}
\hline \multicolumn{2}{|c|}{ Table 11. The effects of phenothiazine derivatives on R123 accumulation on COLO 320 } \\
cell line
\end{tabular}

Numbers with the superscript " indicate cytotoxic effect induced by the particular phenothiazine derivative

${ }^{* *}$ verapamil $(\mathrm{FAR}=4.52)$

On the other hand, in COLO 320 cell line the observed effect of phenothiazines did not differ from that of verapamil positive control, while both phenothiazines had stimulated Rhodamin 123 efflux in cytotoxic concentrations from these cells due to their membrane desintegration.

\begin{tabular}{|c|c|c|c|c|c|}
\hline \multirow[t]{2}{*}{ Samples } & \multicolumn{5}{|c|}{ FAR values at various concentration } \\
\hline & $0.5 \mu \mathrm{g} / \mathrm{mL}$ & $1 \mu \mathrm{g} / \mathrm{mL}$ & $2 \mu \mathrm{g} / \mathrm{mL}$ & $4 \mu \mathrm{g} / \mathrm{mL}$ & $10 \mu \mathrm{g} / \mathrm{mL}$ \\
\hline Verapamil & & & & & 6.89 \\
\hline Perphenazine & 1.02 & 3.21 & 4.48 & 4.50 & \\
\hline Prochlorperazine dimaleate & 0.99 & 3.04 & 3.38 & 4.47 & \\
\hline
\end{tabular}

\section{2. 2. 4 Euphorbia diterpenes}

Our research group previously reported that certain Euphorbia diterpenes may reverse MDR by inhibiting P-gp in human $m d r l$ gene-transfected mouse lymphoma cells (116). Their MDR reversal effects on human colon cancer cell line were also studied (Publication VI).

Compounds 6, 7, 8 and 9 were found to be very strong inhibitors (FAR $=1.49-2.20$ at $4 \mu \mathrm{g} / \mathrm{mL}$ ). For compound 7 , the effect was almost the same at the two concentrations, meaning that both of the applied concentrations were close to the saturation zone. Compounds 1-5 were moderately effective in modulating the P-gp on the resistant human colon cell line. 


\subsection{Interaction of resistance modifier with anticancer drugs}

4.3.1 In vitro effects of cinnamylidene derivatives in combination with doxorubicin As a result of the MDR-reversing experiments, some effective resistance modifier cinnamylidene ketones were selected for combined chemotherapy in the checkerboard microplate method. The results can be seen in Tables 13 .

\begin{tabular}{|c|c|c|c|c|}
\hline \multirow[t]{2}{*}{ Samples } & \multicolumn{2}{|c|}{ L 5178 Y } & \multicolumn{2}{|c|}{ COLO 320} \\
\hline & FIX \pm S. E.M ${ }^{*}$ & Interaction & FIX \pm S. E.M ${ }^{*}$ & Interaction \\
\hline 1 & $0.83 \pm 0.16$ & additive & $0.56 \pm 0.09$ & additive \\
\hline 2 & $0.88 \pm 0.12$ & additive & $0.99 \pm 0.02$ & additive \\
\hline 3 & $1.26 \pm 0.17$ & indifferent & $1.18 \pm 0.14$ & indifferent \\
\hline 4 & $0.36 \pm 0.04$ & synergism & $0.41 \pm 0.02$ & synergism \\
\hline 7 & $1.20 \pm 0.18$ & indifferent & $1.03 \pm 0.03$ & indifferent \\
\hline 8 & $0.41 \pm 0.05$ & synergism & $0.36 \pm 0.05$ & synergism \\
\hline 10 & $1.18 \pm 0.14$ & indifferent & $0.74 \pm 0.19$ & additive \\
\hline 11 & $1.04 \pm 0.03$ & indifferent & $1.14 \pm 0.13$ & indifferent \\
\hline 14 & $1.11 \pm 0.03$ & indifferent & $1.16 \pm 0.05$ & indifferent \\
\hline
\end{tabular}

FIX-fractional inhibitory index; S.E.M were derived at least three FIX values

Synergy was found between doxorubicin and compounds 4 and 8 on L 5178 Y cells. It was interesting that the FIX values of the cinnamylidene-cycloalkanones (1 and 2) revealed additive effects, while compounds $3,7,10,11$ and 14 in combination with doxorubicin were indifferent.

When the same experiment was performed on the COLO 320 cells, only compounds $\mathbf{4}$ and $\mathbf{8}$ were able to enhance the antiproliferative activity of doxorubicin, compounds $\mathbf{1 ,} 2$ and $\mathbf{1 0}$ were shown only marginally additive.

\subsubsection{Interaction between dihydropyridine derivatives in combination with doxorubicin}

The nature of the interactions between doxorubicin and the resistance modifier dihydropyridines also studied on L $5178 \mathrm{Y}$ and COLO 320 cell line. All the selected compounds were able to enhance antiproliferative activity of doxorubicin (Table 14).

Synergy was found between doxorubicin and DL4 on $m d r 1$ gene-transfected mouse lymphoma cell line, but the other combinations resulting in additive effect on both cells. 
Table 14. Interaction between resistance modifier dihydropyridines with doxorubicin on human mdr1 gene-transfected mouse lymphoma ( 5178 Y) and human colon cancer (COLO 320) cell line

\begin{tabular}{|l|c|c|c|c|}
\hline \multirow{2}{*}{ Samples } & \multicolumn{2}{|c|}{ L 5178 Y } & \multicolumn{2}{c|}{ COLO 320 } \\
\cline { 2 - 5 } & FIX \pm S. E.M & Interaction & FIX \pm S. E.M & Interaction \\
\hline DL4 & $0.47 \pm 0.05$ & synergism & $0.58 \pm 0.07$ & additive \\
\hline DL12 & $0.55 \pm 0.04$ & additive & $0.71 \pm 0.07$ & additive \\
\hline DL13 & $0.51 \pm 0.05$ & additive & $0.56 \pm 0.05$ & additive \\
\hline DP89 & $0.55 \pm 0.06$ & additive & $0.59 \pm 0.05$ & additive \\
\hline
\end{tabular}

\subsubsection{Antiproliferative effects of MDR modifier HSP90 inhibitor peptide derivatives in} combination with epirubicin in vitro

Three of the MDR inhibitor peptide derivatives and the anticancer chemotherapeutic epirubicin were studied on multidrug resistant cancer cells in checkerboard assays (Table 15).

\begin{tabular}{|l|c|c|}
\hline \multicolumn{3}{|c|}{ Table 15. Interaction between epirubicin and some peptide resistance modifiers } \\
\hline Samples & FIX \pm S. E.M & Interaction \\
\hline Peptide 1 & $0.37 \pm 0.12$ & synergism \\
\hline Peptide 4 & $0.63 \pm 0.11$ & additive \\
\hline Peptide 5 & $0.52 \pm 0.07$ & additive \\
\hline
\end{tabular}

These MDR inhibitors increased the antiproliferative effect of epirubicin on human MDR1 gene-transfected mouse lymphoma cells resulting from synergism for compound $\mathbf{1}$ and additive antiproliferative effects for compounds 4 and 5. The effect depends on chemical structures.

\subsubsection{Effects of TBN with doxorubicin, paclitaxel and vincristine}

P-gp inhibitory effect of Betti base derivative of tylosin was tested in the presence of representative anticancer agents, such as doxorubicin, paclitaxel and vincristine, on human $m d r l$ gene-transfected mouse lymphoma cells (Table 16).

Table 16. In vitro effects of TBN in combination with doxorubicin, paclitaxel and vincristine on human $m d r 1$ gene transfected mouse lymphoma cells

\begin{tabular}{|l|c|c|}
\hline Anticancer agents & FIX \pm S. E.M & Interaction \\
\hline Doxorubicin & $0.16 \pm 0.05$ & synergism \\
\hline Paclitaxel & $0.61 \pm 0.11$ & additive \\
\hline Vincristine & $0.35 \pm 0.14$ & synergism \\
\hline
\end{tabular}


Strong synergistic effect were observed between TBN and doxorubicin, however the interaction with paclitaxel was additive.

\subsubsection{Interaction between Euphorbia diterpenes with epirubicin on COLO 320 cells}

The enhanced antiproliferative activity of combinations of the diterpene compounds with epirubicin was examined. Synergistic interaction was found between epirubicin and compound 8 (Publication VI). Although compound 9 significantly increased the Rhodamin 123 drug accumulation, did not enhance the antiproliferative effect of the anticancer drug, epirubicin. Diterpenes 3, 6 and 7 had only marginal additive effects.

\subsection{Cellular accumulation and cytotoxicity of doxorubicin in mouse lymphoma cell line in vitro}

Tumour cells with multidrug resistance are able to retain less anticancer drug than their sensitive counterparts. To test whether increased cytotoxicity correlated with enhanced intracellular concentrations of doxorubicin, we exposed the parental and transfected tumour cells to $40 \mu \mathrm{M}$ doxorubicin for $1 \mathrm{~h}$ in the presence or absence of TBN $(10 \mu \mathrm{M})$.

Figure 1. Doxorubicin accumulation and in vitro toxicity after $1 \mathrm{~h}$ doxorubicin exposition on L 5178 Y non-resistant and resistant mouse lymphoma cell lines

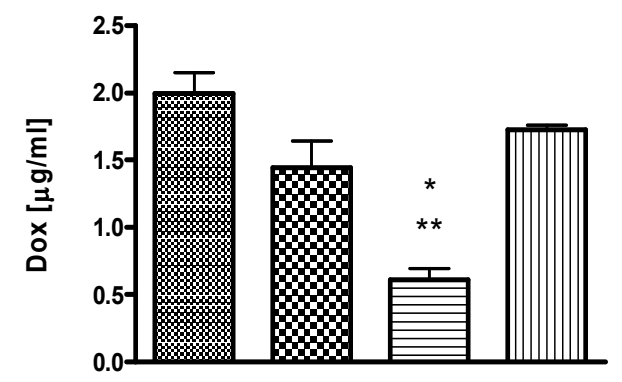

A

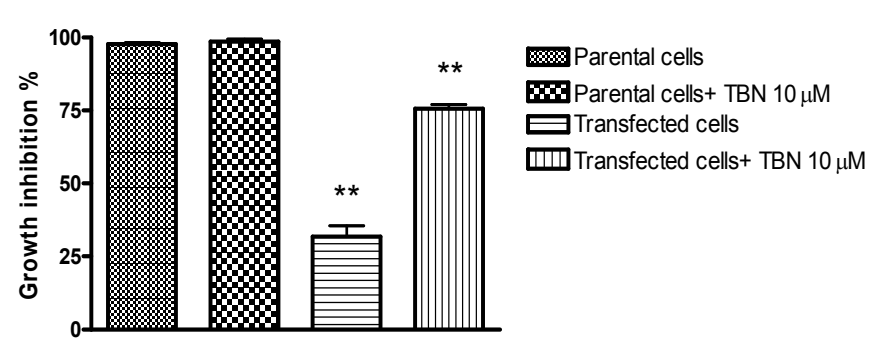

B

Significant differences are indicated by $* p<0.01$ and $* * p<0.001$. Means of "resistant" was found significantly different from non-resistant and treated resistant group respectively in both cases

More than double difference was found between doxorubicin accumulation of the resistant and non-resistant cells. As it was expected TBN treatment was able to restore the sensitivity of resistant cell line to doxorubicin (Figure 1A), whereas it had no significant effect on the accumulation of non-resistant ones.

For the toxicity (Figure 1B) test, the cell density was measured by MTT assay. We found that in this short time experiment (the exposition time was only $1 \mathrm{~h}$ ) the correlation is linear between the accumulation and toxicity in vitro. 


\subsection{In vivo doxorubicin accumulation study in mouse MDR cells}

When doxorubicin was injected intraperitoneal (i.p.), low levels of doxorubicin were detected in the tumour (Figure 2).

Figure 2. Accumulation of doxorubicin in tumour samples after i.p. administration of doxorubicin

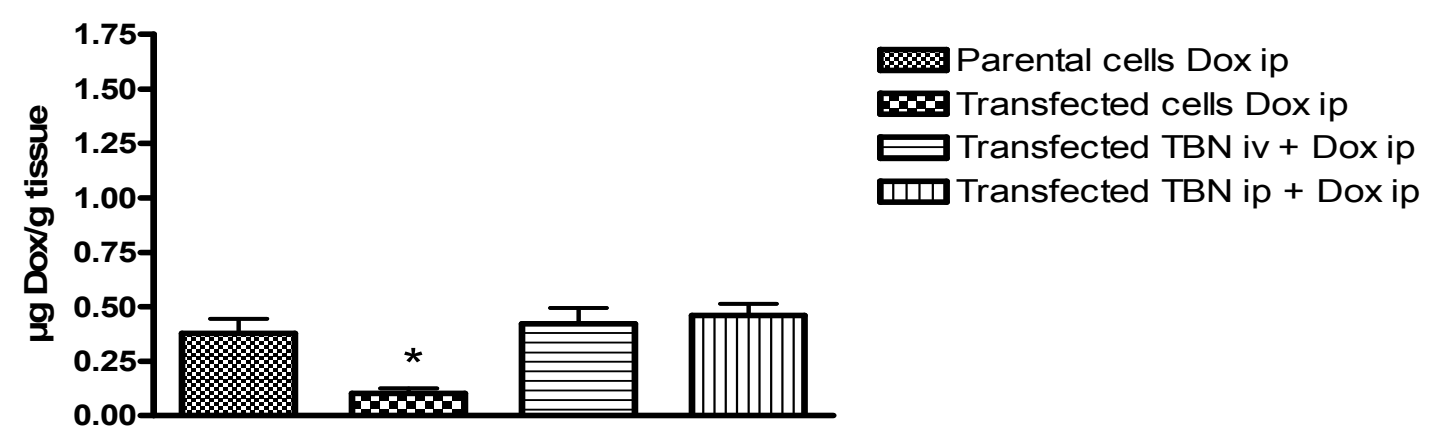

Bars present means \pm SE from seven experiments. Significant difference $(* \mathrm{P}<0.05)$ was found in doxorubicin accumulation of resistant tumour with non-resistant counterpart and both treated samples respectively

TBN was able to enhance the drug accumulation when it was administered intravenously (i.v.) $1 \mathrm{~h}$ or i.p. $3 \mathrm{~h}$ before doxorubicin. However, when TBN and doxorubicin were simultaneously injected, no increase of the doxorubicin could be observed (data not shown). After administering doxorubicin i.v., the recovered amount of drug was much higher as compared to the results obtained after i.p. injections (Figure 3).

Figure 3. Accumulation of doxorubicin in tumour samples after i.v. administration of doxorubicin
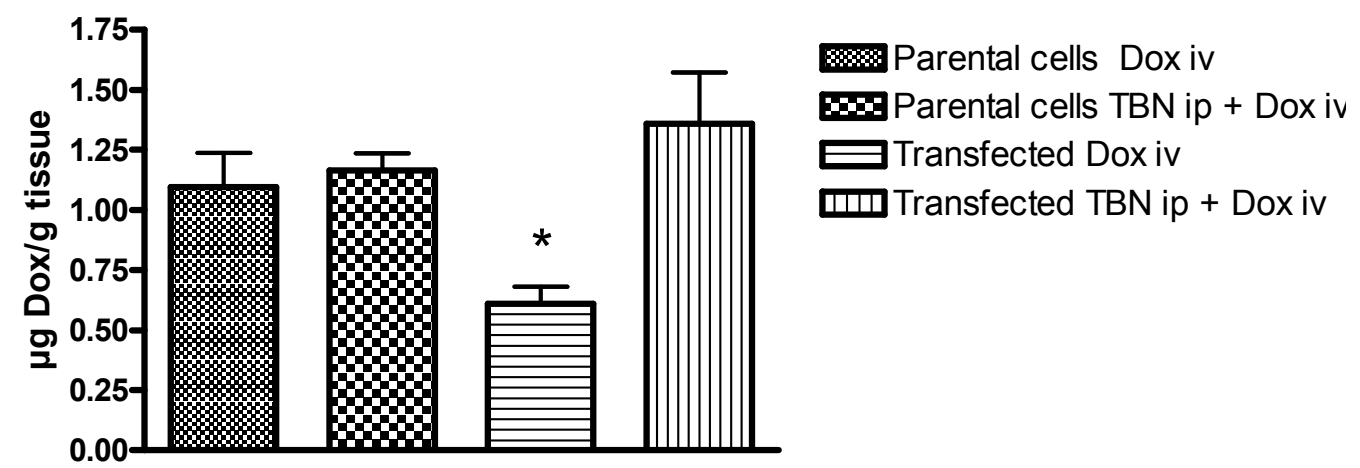

Bars present means \pm SE from seven experiments. Level of significance was evaluated by ANOVA analysis (* means $\mathrm{P}<0.05$ ). 
Furthermore, also in these conditions i.p. administered TBN was able to restore the doxorubicin accumulation in MDR1-expressing tumours to the level of that in tumours consisting of non-resistant cells.

\subsection{Apoptosis induction of some resistance modifiers}

An evaluation of the capacity of the most effective resistance modifiers, as apoptosis inducer, was demonstrated by Annexin-V in flow cytometric analysis and by staining with ethidium bromide and acridine orange, using human $m d r l$ gene-transfected mouse lymphoma cells and a human cervix adenocarcinoma cell line (HeLa).

\subsubsection{Apoptosis induction with FITC-labelled Annexin V and Propidium iodide}

Based on the Rhodamin 123 accumulation and drug interaction experiments, the most effective MDR modifiers cinnamylidene ketones, dihydropyridine derivatives and one Euphorbia diterpene were evaluated as concern apoptosis induction on L 5178 Y cell line (Table 17). The death rate in the presence of the compounds is extremely low. Also low level at early apoptosis was observed in all of the treated cells.

Table 17. Apoptosis induction by the most effective resistance modifier on L 5178 Y cells

\begin{tabular}{|c|c|c|c|c|}
\hline Samples & $\begin{array}{c}\text { Conc. } \\
(\mu \mathrm{g} / \mathrm{mL})\end{array}$ & $\begin{array}{c}\text { Early apoptosis } \\
(\%)\end{array}$ & $\begin{array}{c}\text { Total apoptosis } \\
(\%)\end{array}$ & $\begin{array}{c}\text { Cell death } \\
(\%)\end{array}$ \\
\hline Cell control without & - & 1.14 & 1.22 & 0.06 \\
\hline Cell control + Annexin- $V^{b}$ & - & 8.05 & 11.43 & 1.97 \\
\hline Cell control $+\mathbf{P I}^{\mathbf{c}}$ & - & 0.31 & 1.18 & 2.91 \\
\hline $\begin{array}{lll}\text { Cell } & \text { control double }\end{array}$ & - & 4.83 & 6.93 & 2.98 \\
\hline \multirow{2}{*}{$\begin{array}{l}\text { 12H-benzo( } \alpha) \\
\text { phenothiazine }\end{array}$} & 5 & 77.67 & 99.74 & 0.04 \\
\hline & 25 & 26.25 & 99.55 & 0.03 \\
\hline \multirow[t]{2}{*}{ Diterpene 8} & 2 & 4.04 & 5.80 & 3.36 \\
\hline & 10 & 3.02 & 6.14 & 3.02 \\
\hline \multirow[t]{2}{*}{ Cinnamylidene 4} & 2 & 3.33 & 5.50 & 3.01 \\
\hline & 10 & 2.89 & 3.91 & 1.93 \\
\hline \multirow[t]{2}{*}{ Cinnamylidene 8} & 2 & 4.69 & 6.30 & 1.79 \\
\hline & 10 & 5.37 & 7.16 & 2.48 \\
\hline \multirow[t]{2}{*}{ Dihydropyridine 12} & 2 & 5.56 & 7.89 & 3.05 \\
\hline & 10 & 2.94 & 4.57 & 1.68 \\
\hline \multirow[t]{2}{*}{ Dihydropyridine 13} & 2 & 4.71 & 7.03 & 2.64 \\
\hline & 10 & 6.15 & 12.07 & 2.37 \\
\hline
\end{tabular}

${ }^{\mathrm{a}}$ Annexin-V - negative/propidium iodide-negative samples = intact viable cells (98-100\%)

${ }^{\mathrm{b}}$ Annexin-V - positive/propidium iodide-negative $=$ apoptotic cells

${ }^{\mathrm{c}}$ Annexin-V - negative/propidium iodide-positive $=$ necrotic cells

${ }^{\mathrm{d}}$ Annexin- $\mathrm{V}$ - positive/propidium iodide-positive $=$ apoptotic/necrotic cells

The results are one representative experiment of flow cytometry in which 10000 individual cells were investigated 
The apoptosis inducing effect generally varied between 3 and 13 percent, whereas $12 \mathrm{H}$ benzo $(\alpha)$-phenothiazine led to almost 100 percent apoptosis.

According to this data, all the tested compounds can be considered as moderate apoptosis inducer, except dihydropyridine 13, which showed an increased apoptosis effect at higher concentration.

\subsubsection{The identification of apoptotic and necrotic cells by staining with ethidium bromide and acridine orange (EB/AO)}

The EB/AO staining of the HeLa cells (monolayer) allowed the identification of live, apoptotic and necrotic cells in situ, without trypsin treatment. AO permeates all cells and makes the nuclei appear green. EB is taken up by cells only when the cytoplasmic membrane integrity has been lost; it stains the nucleus red. Even at a lower concentration of compounds $(2 \mu \mathrm{g} / \mathrm{mL})$, treatment of HeLa cells with possible MDR modifiers led to the typical morphological features of apoptosis, including increased cell membrane permeability, cellular shrinkage and granulation in the nucleus. Figure 4. shows the fluorescent microscopic pictures of one representative samples, diterpene 8-treated HeLa cells after a $24 \mathrm{~h}$ incubation.

Figure 4. EB/AO staining of diterpene 8-treated HeLa cells

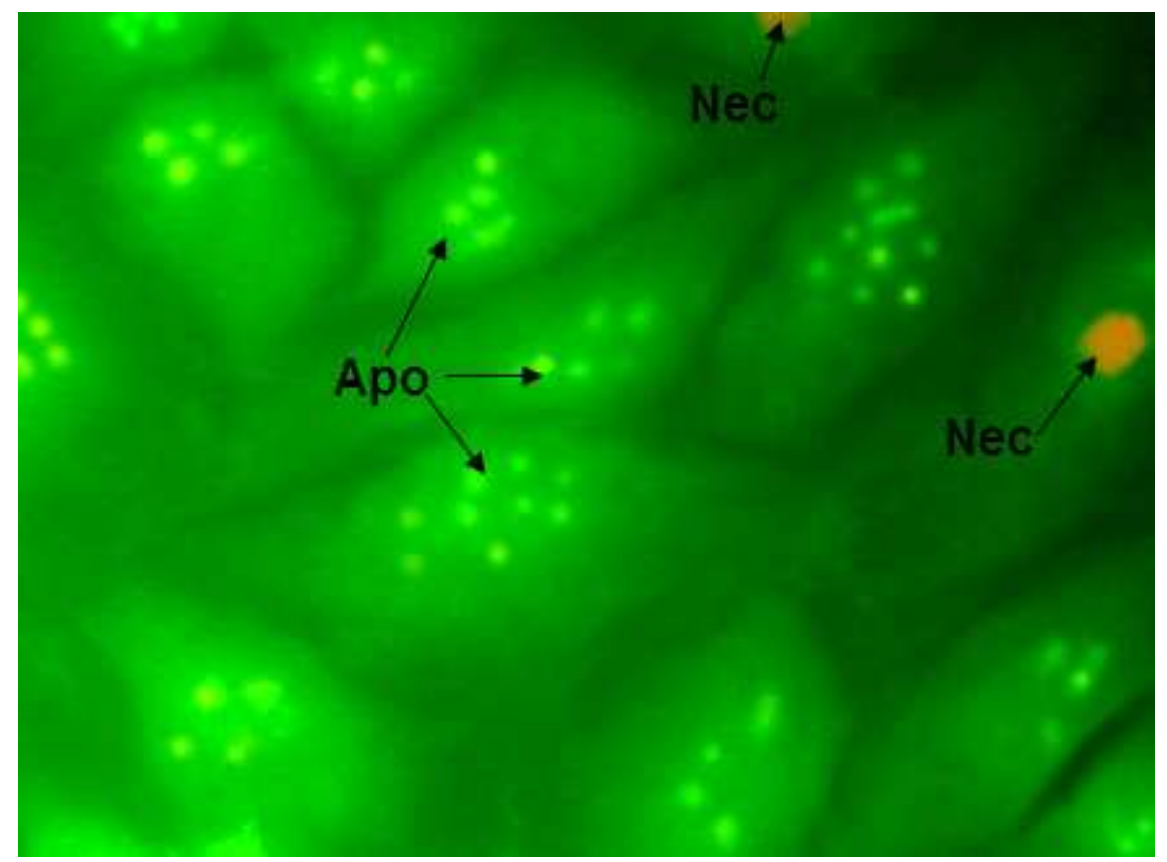

"Apo" indicates cellular shrinkage and nuclear granulation characteristic of apoptosis; "Nec" indicates necrosis evidence by fluorescence of ethidium bromide 


\subsection{Anti-promotion effect of plant derivatives}

As a model for prevention of cancer progression by CMV infection, the antitumour-promotion effects of some lathyrane-type diterpenoids were studied in vitro.

To develop an objective method for studying antipromotion effect, the compounds had to be applied in non-toxic doses. Based on the $\mathrm{ID}_{50}$ values, then $\mathrm{ID}_{1}$ and $\mathrm{ID}_{10}$ inhibitory doses were tested for modification of CMV IE antigen expression in the different lathyrane-treated lung cancer cells (A549) cells.

The results are summarized in Table 18. Latilagascenes B-C (2-3), E (5) and jolkinol B (6) showed inhibitory activity in a dose dependent manner against IE antigen expression of CMV. Latilagascene $\mathrm{A}(\mathbf{1})$ in dose $\mathrm{ID}_{1}$ was more effective than $\mathrm{ID}_{10}$ in inhibition of production of IE antigen. It is assumed that both doses might be in the dose saturation region concerning the biological effect. This explanation is supported by the lowest $\mathrm{ID}_{50}$ value of the latilagascene $\mathrm{A}$ (1). Latilagascene D (4) was inactive due to the steric properties.

The inhibition of IE antigen expression of CMV in the presence of non-toxic doses of lathyranes was evaluated as antipromoting effect that can reflect the chemopreventive activity of a compound.

\begin{tabular}{|l|c|c|}
\hline $\begin{array}{l}\text { Table 18. The effects of lathyrane diterpenes 1-6 on human cytomegalovirus IE gene } \\
\text { expression }\end{array}$ & $\begin{array}{c}\text { IE antigen expressing cells } \\
\text { (\% of control) }\end{array}$ \\
\hline Compounds & ID $^{\text {a }}$ & 61 \\
\hline Latilagascene A (1) & 1 & 79 \\
\hline Latilagascene B (2) & 10 & 91 \\
\cline { 2 - 3 } & 1 & 80 \\
\cline { 2 - 3 } & 10 & 74 \\
\cline { 2 - 3 } & 1 & 63 \\
\hline \multirow{2}{*}{ Latilagascene C (3) } & 10 & 95 \\
\cline { 2 - 3 } & 1 & 95 \\
\hline \multirow{2}{*}{ Latilagascene E (5) } & 10 & 74 \\
\hline Jolkinol B (6) & 1 & 51 \\
\cline { 2 - 3 } & 10 & 69 \\
\cline { 2 - 3 } & 1 & 54 \\
\hline
\end{tabular}

${ }^{a}$ ID: Inhibition dose for A549 cells 


\section{DISCUSSION}

The development of pharmacological agents able to counteract the mechanisms of multidrug resistance in oncology has remained a major goal for the past ten years. Several mechanisms are thought to be involved in drug resistance, including those associated with drug transport, detoxification and apoptosis.

The first part of this thesis was focused on the inhibition of MDR through inhibition of the MDR P-glycoprotein in various cell lines. Six groups of compound were involved in the P-gp efflux pump inhibitory studies: cinnamylidene ketones; 1,4-dihydropyridines derivatives; phenothiazines; HSP90 inhibitor peptide derivatives; Tylosin Betti base derivative and Euphorbia diterpenes.

The cytotoxic effects of some cinnamylidene ketones and their derivatives against P388 lymphocytic leukaemia and murine L1210 lymphoid leukaemia were described by Dimmock et al. (117, 118). 2-(2-methoxycinnamylidene)indan-1-one (4), 2-cinnamylidene3,4-dihydro-2H-naphthalen-1-one (7), 2-(2-methoxycinnamylidene)-3,4-dihydro-2Hnaphthalen-1-one (8), 6-cinnamylidene-6,7,8,9-tetrahydrobenzocyclohepten-5-one (10) and 6-(2-methoxycinnamylidene)-6,7,8,9-tetrahydrocyclohepten-5-one (11) display marked effectivity for the reversal of the MDR on human $m d r l$ gene-transfected mouse lymphoma cells and human colon cancer cell line (COLO 320). In the case of the COLO 320 cells, which express the $m d r l$ gene, the degree of Rhodamin 123 accumulation was lower than on the artificially constructed extremely sensitive mouse lymphoma cells, in which P-gp is overexpressed (106). This means that the effectivity of the reversal compounds also depends on the "type" of cancer cells, which express more or less vulnerable P-gp.

Two of the tested compounds, namely, 2-(2-methoxycinnamylidene) indan-1-one (4) and 2(2-methoxycinnamylidene)-3,4-dihydro-2H-naphthalen-1-one (8) were able to enhance the antiproliferative activity of doxorubicin in a synergistic way. Similar studies illustrated that combined application of above mentioned two compounds with paclitaxel, docetaxel or vincristine exerted significant antiproliferative effects on the resistance sublines of MCF7 (119).

1,4-Dihydropyridines are well known as $\mathrm{Ca}^{2+}$ channel blockers and as drugs for the treatment of cardiovascular diseases, including hypertension (120). The 1,4-dihydropyridine 
heterocyclic ring is a common feature of various bioactive compounds, such as vasodilator, bronchodilator, antitubercular agents $(121,122)$, and more recently MDR modulators and antitumour agents (123-125).

The MDR-reversing effects of the dihydropyridines having been tested in MDR reversal experiments. Most of the 1,4-dihydropyridines considered as potent inhibitors of multidrug resistance. The high anti-MDR potency of selected dihydropyridines (DL4, DL12, DL13 and DP89) were also very effective in combination with doxorubicin. Some dihidropyridines at the higher concentrations used were found to be toxic, but at low doses most of the derivatives were able to increase the R123 accumulation without toxic effects.

Phenothiazines, apart from their wide range of biological activity (126) have been described as effective MDR modifiers. During the last few years, many new phenothiazine derivatives have been synthesized and their activity has been extensively studied (127-129).

The tested phenothiazines were moderately active resistance modulators, especially in the low concentration. The higher concentration, appeared cytotoxic, however, this effect was more profoundly accentuated in MDR1-expressing mouse T-cell lymphoma cell line than in COLO 320 cell line. The toxic effect and MDR reversal of phenothiazine derivatives on tumour cells has been described previously by Wesołowska et al. (130), who reported that the phenothiazine maleates were more toxic than other derivatives tested. These observations are in agreement with our results, where methotripromazine maleate and prochlorperazine dimaleate caused decreased cell survival of the two cell lines studied. According to the observations of Flores et al. (131) phenothiazine hydrochlorides are also characterized by high cytotoxicity. Similarly, in our experiment, trifluoropromazine hydrochloride was toxic. The above-mentioned authors claim that the phenothiazines, exemplified by phenothiazine hydrochlorides, are able to modify cell membrane properties by disorganization of functionally active conformation of P-gp and the phospholipids; translocation of antitumour drug complexes through the membrane. On the other hand, the same ability could also benefit in modulation of MDR. Actually, if the drug concentration were reduced, obviously it would behave as an effective MDR inhibitor and did not cause cell death. According to the Flores et al. (131), the MDR reversal in L5178 Y and COLO 320 cell lines by phenothiazines might be mediated by two alternative mechanisms: by changing the conformation of lipids in the membranes, and, when combined with other drugs, by acting as carriers of insoluble antitumour agents to target proteins of cell interior. 
Heat shock protein 90 (Hsp90) inhibitor peptides arrests the growth of cancer cells (132). Their ability to reverse the MDR of tumour cells was also investigated, in order to obtain additional evidence concerning the relationship between chemical structure and biological activity. A structure-activity relationship was observed in the MDR reversal effect since two of the three strongly hydrophobic compounds (1 and 4) were the most potent. The correlation between the inhibition of the $\mathrm{ABC}$ transporter and the chemical properties of the active compounds is possibly similar to that for a certain group of carotenoids in which the total polar surface areas of the hydrophobic compounds exhibited some correlation with the MDRreversal effects (133). $D$-Trp-Phe- $D$-Trp-Leu-AMB (1), which has a relatively high apolar character, and its succinylated derivative, Suc- $D$-Trp-Phe- $D$-Trp-Leu-AMB (4) which is slightly more water soluble demonstrated the highest fluorescence activity ratios. Interestingly, replacing the $N$-terminal $D$-Trp of 1 by $D$-Tyr to obtain $D$-Tyr-Phe- $D$-Trp-Leu-AMB (5) caused a dramatic change in the fluorescence activity ratio, indicating that the indole side-chain at this position is indispensable for the biological effect, and for the reversal of MDR of cancer cells. The low activity compounds revealed that introduction of a free carboxamide or carboxyl group at the $C$-terminus (peptide derivatives $2,3 \mathbf{6 , 7 , 8 , 9}$ and 10) or introduction of a reduced peptide bond in the chain (peptide derivatives $\mathbf{2}$ and 7) were not functionally important structural factors. It should be noted that the activity of the peptide derivatives in reversing the MDR did not depend upon the length of the peptide chain: rather, it depended on the stacking ability of tryptophan, and the tetrapeptide structure proved best from this respect. Orosz et al. reported that the 10 tested peptide derivatives exerted noteworthy antiproliferative effects on various human small-cell-lung cancer, colorectal and mammary adenocarcinoma cells. It was also found in the in vivo model experiments that growth inhibitors inhibited tumour growth in nude mice bearing the xenografts without general toxicity $(134,135)$.

These MDR inhibitors increased the antiproliferative effect of epirubicin on human $m d r 1$ gene-transfected mouse lymphoma cells resulting from synergism for compound $\mathbf{1}$ and additive antiproliferative effects for compounds $\mathbf{4}$ and $\mathbf{5}$.

In order to get better insight into structure activity relationship in vitro P-gp inhibitory effects of N-Tylosil-1-a-amino-(3-bromophenyl)-methyl-2-naphtanol (TBN) and its precursor moieties (tylosin and Betti base) were also studied. Since macrolide antibiotic erythromycin was reported as a possible P-gp inhibitor (136) it was supposed that tylosin part of TBN has a crucial role in P-gp modulator activity. Interestingly, only slight effect of tylosin was 
observed in inhibition of drug efflux and in vitro interaction studies compared to TBN. Differences were very appreciable in their effect on R123 efflux studies between precursors and TBN. TBN treatment was resulted significantly higher activity in P-gp inhibition than its two-precursor moiety. This finding also suggests that the molar weight and lipophilicity of compound has a crucial role in P-gp substrate specifity and/or inhibition as it was previously reported by Didziapetris et al. (137). Further experiments were focused on the effect of TBN. Significant synergism was observed in vitro combination of TBN and doxorubicin and/or vincristine on mouse lymphoma cell line.

Before in vivo studies, we attempted to determine the relationship between doxorubicin accumulation and toxicity. Linear correlation was found between the toxicity and increased accumulation of doxorubicin however the cells were exposed to higher concentration of doxorubicin in short time incubation. Smaller differences were achieved in doxorubicin accumulation between resistant and non-resistant or TBN treated and none treated cells if it is compared to the results of R123 accumulation study (data not shown). Since the lipid peroxidation activity of anthracyclines is appreciable under defined condition (138) in this experiment the results of doxorubicin accumulation and toxicity might be influenced by membrane damage of the cells. An important site of cytotoxic action of doxorubicin is the nucleus, where doxorubicin intercalated into DNA, forming DNA adducts and inhibition topoisomerase II (139).

The in vitro activity of TBN was confirmed in further in vivo efficacy studies. The combination of doxorubicin with TBN increased the doxorubicin concentration in the tumours compared with doxorubicin alone using DBA/2 mice bearing syngeneic L 5178 Y tumours. In case of applied regimens of $\mathbf{T B N}$ on resistant tumours, the doxorubicin level was similar as in non-resistant tumours due to the inhibited efflux of MDR cells. Independently from doxorubicin administration (i.v. or i.p.), TBN treatment was able to restore the doxorubicin sensitivity of resistant tumours. The efficacious dose of TBN seemed relatively low and coadministration with doxorubicin is well tolerated. Our study suggests that TBN is a very promising P-glycoprotein inhibitor with low toxicity and relatively high efficacy.

Euphorbia species have been used in traditional medicine in many countries to treat cancer and warts (140). Besides the presence of highly skin-irritant compounds (phorboids) (141, 142), Euphorbia species are of further considerable interest owing to a large diversity of 
structurally unique and non-irritant jatrophane and lathyrane diterpenoid constituents, which have been considered to be potent modulators of $\operatorname{MDR}(143,144)$. Our research group previously reported that extracts containing macrocyclic diterpenes may reverse MDR by inhibiting P-gp in human $m d r l$ gene-transfected mouse lymphoma cells (114-116).

Three of the tested diterpene derivatives $(6,8$ and 9) displayed a significant concentrationdependent effect in inhibiting the efflux pump activity on the COLO 320 cell line. The most effective synergistic effect was found between compound $\mathbf{8}$ and epirubicin. The strong activity of this derivative can be explained by its high lipophilicity, but other parameters, such as the presence of functional groups, may also be involved in the synergistic effect and in the interaction with P-gp. The numbers of double bonds, pseudorotation of the ester groups and transannular interactions of the substituents have significant effects on the stereostructure and the activity of the molecules. It is known that the conformational flexibility of the twelvemembered ring of the jatrophanes is strongly influenced by the steric interactions of the substituents. On comparison of the efficacies of compounds $\mathbf{7}$ and $\mathbf{8}$, it can be presumed that the presence of a hydroxy group instead of peracylation is favourable as concerns the antiproliferative activity in combination with epirubicin.

Although compound 9 significantly increased the R123 accumulation in COLO 320 cells, in combination with epirubicin it had no antiproliferative effect on the tested cell line. The differences between the dose-dependent antiproliferative and the MDR-reversal effects of studied derivatives can be consequences of the various experimental procedures, including the different incubation times, and possible metabolisms of compounds.

Many classes of antitumour drugs, including naturally occurring and pharmaceutical compounds, induce apoptosis in cancer cell $(15,16)$. Apoptosis is typically induced by the activation of membrane receptors, cell cycle arrest, p53 activation by DNA damaging agents and mitochondria pore transition permeability (11). The apoptotic process is characterized by particular morphological and ultrastructural features, which can be evidenced by several assays, including FITC-conjugated annexin V method or acridine orange assay (111).

In our study the tested compounds (cinnamylidene $\mathbf{4}$ and $\mathbf{8}$, dihydropyridine $\mathbf{1 2}$ and Euphorbia diterpene 8) were able to induce moderate apoptosis in human $m d r l$ genetransfected mouse lymphoma cell line. The most promising apoptosis inducer was the dihydropyridine substituted compound 13, however, the levels of total apoptosis were much lower in every case than positive control $12 H$-benzo[ $\alpha]$ phenothiazine (M-627). The annexin V positivity of treated-cells by various compounds could be a consequence of the structural 
alteration in cell membrane, which results in the translocation of phosphatidylserine molecules from the inside to the outer surface of the membrane (111). The apoptosis inducing effect of MDR reversal compounds can have special importance in experimental chemotherapy.

Carcinogenesis is a multistage process by which a normal cell is transformed into a cancerous cell. Transformation involves initiation, usually from DNA damaging agents, promotion, during which cell proliferation is increased, and progression, involving additional genetic alterations (145). Cancer chemoprevention is defined as the use of natural, synthetic, or biological agents to prevent, suppress, or reverse either the initiation phase of carcinogenesis or the carcinogenic progression (146) and promotion.

The mechanism of action of chemopreventive compounds acting as antitumour-promoters is not exactly known. However, a significant number of them have been considered to inhibit the tumour promotion stage by interacting with the protein kinase $\mathrm{C}$ which plays a crucial role for the regulation of cell growth (147).

In the present work, the human CMV was used in a modified in vitro model for characterizing lathyrane compounds with antipromotion effect on human lung cancer cells (A549). The ability of human CMV to preferentially infect tumour tissues suggests a unique character of mutual interaction between the mechanisms of tumour cells and human CMV (101). IE gene products of the virus accumulate in the infected cells causing disturbances of host cell functions. The oncomodulatory effects of human CMV infection may lead to a shift to more malignant phenotype of tumour cells contributing to tumour progression (148).

The structures of the six studied compounds differ in the substitution pattern of ring A having compound 5 also a different substitution at C-20 where the methyl group is oxidized, having been replaced by a $-\mathrm{CH}_{2} \mathrm{OH}$. This structural feature appears to be important justifying the activity difference between latilagascene D (4) and latilagascene E (5) which showed the highest activity as anti-promoters. The comparison of the activity of compounds $\mathbf{4}$ and $\mathbf{1}$, whose structures differ only at the ester group at C-16, suggests that the presence of the benzoyl moiety in the former has a negative action in the inhibitory effect.

This study revealed that certain macrocyclic lathyrane-type diterpenoids may be promising lead compounds for natural product-based drug development. Similar results were found an inhibition of adenovirus and EBV early antigen expression both in vitro (149) and in vivo (150) by inhibition of skin tumour promotion in mice. 


\section{NEW STATEMENTS}

I. Based on the antiproliferative or cytotoxic effect differences were found between sensitive and MDR tumour cells.

II. During my PhD study, several groups of compounds were identified as MDR modulators (cinnamylidene ketones; 1,4-dihydropyridines; phenothiazines; HSP90 inhibitor peptides; Betti base derivative of tylosin and some naturally occurring plant derived jatrophane and lathyrane-type diterpenes).

A majority of the tested cinnamylidene derivatives were able to increase the R123 accumulation in human $m d r l$ gene-transfected mouse lymphoma cell line (L $5178 \mathrm{Y}$ ) and also in human colon cancer cells (COLO 320). The MDRreversing effect of tested of cinnamylidenes were markedly lower in COLO 320 cells as compared with L 5178 Y cell line. The reason for this phenomenon could be the fact that P-glycoprotein expression in COLO 320 cell line is lower than in L 5178 Y cells.

Numerous tested 1,4-diphenyl-1,4-dihydropyridine derivatives reversed the MDR of tumour cells more effectively than the reference compound, verapamil.

Two of the phenothiazine derivatives namely perphenazine and prochlorperazine dimaleate proved to be effective inhibitors of Rhodamin 123 efflux. Other tested phenothiazine derivatives also modulated intracellular drug accumulation in resistant cell lines.

Among the synthetic HSP90 inhibitor peptide derivatives two of the strongly hydrophobic compounds (compound $\mathbf{1}$ and 4) were the most potent in MDR reversal.

TBN ( $N$-tylosil-1- $\alpha$-amino-(3-bromophenyl)-methyl-2-naphthol), and not the individual Betti-base and tylosin moieties, is able to increase the cellular uptake of the fluorescent P-gp substrate Rhodamin 123 in human $m d r l$ gene transfected mouse T-cell lymphoma drug resistant cell line L $5178 \mathrm{Y}$, and fully reversed the cellular resistance against doxorubicin.

It seems that the effect of Euphorbia diterpenes on MDR reversal effect of tumour cells depends on the chemical structure. The presence of hydroxy group instead of peracylation is favourable on COLO 320 cells.

III. Generality, the newly identified MDR modifiers were able to enhance the antiproliferative activity of selected anticancer drugs (e.g. doxorubicin, paclitaxel and vincristine) in a synergistic or additive way in vitro on MDR cells.

The in vivo results shown, that co-administration of $\mathbf{T B N}$ with doxorubicin significantly increased the antitumour activity of doxorubicin in DBA/2 mice.

IV. As an alternative way of antitumour effect, apoptosis inductions of resistance modifiers were studied. 
The substituted dihydropyridine $\mathbf{1 3}$ was the most promising apoptosis inducer on L 5178 Y cells during the 1 hour incubation.

Typical apoptotic markers were observed after a $24 \mathrm{~h}$ treatment with the tested jatrophane derivative $\mathbf{8}$ by staining with ethidium bromide and acridine orange on HeLa cells.

V. As a model for prevention of cancer progression by CMV infection, the antitumour-promotion effects of some resistance modifiers were studied. All the six macrocyclic lathyrane-type diterpenoids, could reduced the promotion in vitro, except latilagascene $\mathrm{D}$, decreased IE-antigen expression of CMV to prevent progression of tumour malignancy. 


\section{7. ÖSSZEFOGLALÓ}

A daganatos megbetegedések elleni küzdelem hatásosságában a multidrog rezisztencia (MDR) kérdés megoldása fontos szerepet játszik. Növekvő igény mutatkozik olyan új vegyületek kifejlesztésére, melyek képesek gátolni a különböző rezisztencia mechanizmusokat.

Célul tüztük ki a szintetikus (cinnamilidén ketonok, 1,4-dihidropiridin és fenotiazin származékok, HSP90 gátló peptidek és Tilozin betti bázisú származék), valamint természetes növényi alkotókból (Euphorbia diterpének) kivont származékok MDR-efflux pumpa gátlás vizsgálatát különböző sejtvonalakon, remélve, hogy kevésbé toxikus, de annál hatásosabb rezisztenciamódosító vegyületeket találunk. A különböző MDR módosító vegyületeket in vitro és in vivo kísérletekben kombináltuk rákellenes szerekkel.

A cinnamilidén ketonok közül a, 2-(2-metoxicinnamilidén) indán-1-on (4), 2cinnamilidén-3,4-dihidro-2H-naftalén-1-on (7), 2-(2-metoxicinnamilidén)-3,4-dihidro-2Hnaftalén-1-on) (8), 6-cinnamilidén-6,7,8,9-tetrahidrobenzocikloheptén-5-on (10) és 6-(2methoxicinnamilidén)-6,7,8,9-tetrahidrocikloheptén-5-on (11), jelentős MDR visszafordító hatást fejtett ki a humán $m d r 1$ gén-transzfektált egérlymphoma (L 5178 Y), valamint humán vastagbélrák sejteken (COLO 320). Közülük, kettő (4 és 8-as jelölésű vegyület) szinergizálta a doxorubicin sejtszaporodásgátló hatását.

Az 1,4-dihidropiridinek többsége hatásos MDR revertáló vegyületnek bizonyult. Néhányuk magasabb koncentrációban toxikus hatást mutatott, azonban alacsonyabb dózisban legtöbbjük képes volt a Rhodamin 123 sejtekben való felhalmozódás fokozására, sejtkárosodás nélkül. Kiválasztott dihidropiridin származékok (DL4, DL12, DL13 és DP89) szintén hatásosak voltak doxorubicinnel kombinálva.

Fenotiazinok közül a perfenazin és proklorperazin dimaelat jelentős Rhodamin 123 efflux gátlást mutatott L 5178 Y és COLO 320 sejtvonalakon. A többi fenotiazin származék mérsékelt hatású volt, magasabb koncentrációban toxicitásuk is megjelent.

Hősokk fehérje 90 (Hsp90) gátló peptidek közül a $D$-Trp-Phe- $D$-Trp-Leu-AMB (1), mely viszonylag jelentős apoláris tulajdonsággal rendelkezik, és szuccinilált származéka, Suc- $D$ Trp-Phe- $D$-Trp-Leu-AMB (4), mely vízoldékonyabb, a legmagasabb fluoreszcencia értékeket mutatták kísérleteinkben.

A vizsgált diterpén származékok közül három (6, 8 és 9), szignifikáns koncentrációfüggő efflux pumpa gátló hatást váltott ki COLO 320 sejtvonalon. A legjelentősebb szinergizálló hatást epirubicin és Euphorbia diterpén $\mathbf{8}$ együttes alkalmazásánál tapasztaltuk. Annak 
ellenére, hogy a 9-es vegyület vastagbélrák sejtekben megnövelte az R123 felhalmozódását, az epirubicinnel való kombináció alkalmával nem mutatott kölcsönhatást a rákellenes szerrel, a vizsgált sejtvonalon. A dózis-függő antiproliferatív és MDR gátló kísérletekben tapasztalt különbségekért, a különböző kísérleti módszerek, beleértve az inkubációs idők hosszát és a vegyületek lehetséges metabolitikus változását, tehetők felelösé.

Kísérleteinkben modellként használt egérlymphoma sejtvonal, melyben fokozott MDR1 expresszió figyelhető meg, érzékenyebbnek bizonyult a vizsgált vegyületekre, mint a humán vastagbélrák sejtvonal, ugyanis már a legkisebb pumpa gátló hatás is érzékelhető benne.

TBN ( $N$-tilozil-1- $\alpha$-amino-(3-bromofenil)-metil-2-naftol) kezelés jelentős P-gp gátló hatást mutatott L 5178 Y sejteken és fokozta a doxorubicin illetve vincristin sejtszaporodásgátló hatását in vitro kísérleteinkben. Megnövelte rezisztens sejtek érzékenységét doxorubicinnel szemben, de nem idézett elő szignifikáns változást a nem-rezisztens sejteknél. Egyenes arányosságot tapasztaltunk a doxorubicin felhalmozódás és toxicitás között. Doxorubicinnel való együttes alkalmazásánál, megnövelte annak felhalmozódását L 5178 Y tumorsejtvonalat hordozó DBA/2 egerekben, függetlenül a doxorubicin adagolás módjától (i.v. vagy i.p.).

Megvizsgáltuk egyes vegyületeink apoptózis indukáló hatását is. Kísérletünkben a cinnamilidén 4 és 8, dihidropiridin 12 illetve Euphorbia diterpén 8 mérsékelt apoptotikus hatást fejtett ki humán $m d r l$ génnel-transzfektált egérlymphoma sejtvonalon. A leghatásosabb apoptózis indukáló a dihidropiridin 13 volt, annak ellenére, hogy az általa kiváltott teljes apoptózis mértéke alacsonyabb volt, mint a pozitív kontrol $12 H$-benzo $\alpha$ ]fenotiazinak (M$627)$.

Számos esetben leírták, hogy a humán cytomegalovírus (CMV) képes tumorszövetek fertőzésére, a vírus korai (IE) antigénjei felszaporodnak a tumorsejtekben és a daganat további malignizációját segítik. CMV korai antigén expresszió gátlása arra utalhat, hogy az antipromóciós hatás érvényesült. In vitro modell kísérletünkben, humán tüdőrák sejtvonalon, a vizsgált makrociklikus latrán típusú diterpén vegyületek többsége képes volt a CMV korai antigén kifejeződés gátlására. 


\section{ACKNOWLEDGEMENTS}

I am deeply grateful to my supervisor Professor József Molnár for his continuous support and encouragement throughout my $\mathrm{PhD}$ studies. I also express many thanks to his kind help, skilful guidance and inspiration.

I greatly acknowledge to Professor Yvette Mándi for providing working facilities at the department of Medical Microbiology and Immunobiology.

I owe Professor Rozália Pusztai my thanks for her help and constructive comment.

I am grateful to Dr. Imre Ocsovszki for performing the flow-cytometric measurements.

I would like to show gratitude to my colleague, Dr. Nóra Gyémánt for her scientific help.

I thank Anikó Váradi Vigyikán for her excellent technical assistance in the laboratory work.

I wish to thank all my co-workers, colleagues and staff members at the Department of Microbiology and Immunobiology, University of Szeged, are gratefully thanked for creating a supportive and pleasant working environment.

Finally, I heartfully thank my parents, my love and my friends for their support, love and patience through all these years.

This thesis was supported financially by the Foundation for Cancer Research of Szeged (Szegedi Rákkutatásért Alapítvány) and Flemish-Hungarian Intergovernmental Cooperation Program for 2005-2006 (B-31/04). 


\section{REFERENCES}

1. Levi F, Lucchini F, Negri E and La Vecchia C: Trends in mortality from major cancers in the European Union, Including acceding countries, in 2004. Cancer 101: 2843-2850, 2004.

2. Ferlay J, Autier P, Boniol M, Colomber M and Boyle P: Estimated of cancer incidence and mortality in Europe in 2006. Annals of Oncol 18: 581-592, 2007.

3. Primic-Zakelj M, Zadnik V and Zagar T: Is cancer epidemiology different in Western Europe to that in Easten Europe? Annals of Oncol 16: 27-29, 2005.

4. Ottó Sz: Cancer epidemiology in Hungary and Béla Johan National Program for the decade health. Pathology Oncol Res 9: 126-130, 2003.

5. Cooley ME, Sarna L, Brown JK, Williams RD, Chernecky C, Padilla G, Danao LL and Elashoff D: Tobacco use in women with lung cancer. Ann Behav Med 33: 242-250, 2007.

6. Boccia S, Cadoni G, Sayed-Tabatabaei FA, Volante M, Arzani D, De Lauretis A, Cattel C, Almadori G, van Duijn CM, Paludetti G and Ricciardi G: CYP1A1, CYP2E1, GSTM1, GSTT1, EPHX1 exons 3 and 4, and NAT2 polymorphisms, smoking, consumption of alcohol and fruit and vegetables and risk of head and neck cancer. J Cancer Res Clin Oncol. 2007 in press

7. Liu CJ and Kao JH: Hepatitis B virus-related hepatocellular carcinoma: epidemiology and pathogenic role of viral factors. J Chin Med Assoc 70:141-145, 2007.

8. Chan JK and Berek JS: Impact of the human papilloma vaccine on cervical cancer. J Clin Oncol 25: 2975-2982, 2007.

9. Makola D, Peura DA and Crowe SE: Helicobacter pylori infection and related gastrointestinal diseases. J Clin Gastroenterol 41: 548-558, 2007.

10. Biggar RJ, Chaturvedi AK, Goedert JJ and Engels EA: AIDS-related cancer and severity of immunosuppression in persons with AIDS. J Natl Cancer Inst 20: 962-972, 2007.

11. Kaufman DC and Chabner BA: Clinical strategies for cancer treatment: the role of drug, in: Cancer Chemotherapy \& Biology, third ed., Lippincott, Williams and Wilkins, pp. 1-16, 2001.

12. Espinosa E, Zamora P, Feliu J and Barón MG: Classification of anticancer drugs- a new system based on therapeutic targets. Cancer Treatment Reviews 29: 515-523, 2003.

13. Skeel RT and Lachant NA: Handbook of Cancer Chemotherapy. Fourth Edition, 2005.

14. Tolomeo M and Simoni D: Drug resistance and apoptosis in cancer treatment: development of new apoptosis-inducing agents active in drug resistance malignancies. Curr Med Chem Anticancer Agents 2: 387-401, 2002.

15. Duarte N, Varga A, Cherepnov G, Radics R, Molnár J and Ferreire MJ: Apoptosis induction and modulation of P-glycoprotein mediated multidrug resistance by new macrocyclic lathyrane-type diterpenoids. Bioorg Med Chem 15: 546-554, 2007.

16. Varga A, Aki-Sener E, Yalcin I, Temiz-Arpci O, Tekiner-Gulbas B, Cherepnev G and Molnár $\mathrm{J}$ : Induction of apoptosis and necrosis by resistance modifiers Benzoazoles and Benzoxazines on tumour cell line mouse lymphoma L5178 mdr+ cells. In Vivo 9: 1087-1092, 2005.

17. Ugocsai K, Varga A, Molnár P, Antus S and Molnár J: Effects of selected flavonoids and carotenoids on drug accumulation and apoptosis induction in multidrug resistance colon cancer cells expressing MDR1/LRP. In Vivo 19: 433-438, 2005.

18. MacFarlane $M$ and Williams C: Apoptosis and disease: a life or death decision. EMBO Reports 7: 674-678, 2004.

19. Cory AH and Cory JG: Understanding interactions between and among apoptosis inducing pathways in tumour cells. In Vivo 21: 245-250, 2007.

20. Kaufmann SH and Earnshaw WC: Induction of apoptosis by cancer chemotherapy. Exp Cell Res 256: 42-49, 2000.

21. Corazzari M, Lovat PE, Oliverio S, SiSano F, Donnorso RP, Redfern PF and Piacenti M: Fenretinide: a p53 independent was to kill cancer cells. Biochem Biophys Res Commun 331: 810-815, 2005.

22. Darzynkiewicz Z, Juan G, Li X, Gorczyca W, Murakami T and Traganos F: Cytometry in cell necrobiology: analysis of apoptosis and accidental cell death (necrosis). Cytometry 27: 1-20, 1997. 
23. Cohen GM, Su XM, Snowden RT, Dinsdale D and Skilleter DN: Key morphological features of apoptosis may occur in the absence of internucleosomal DNA fragmentation. Biochem $\mathrm{J}$ 286: 331-334, 1992.

24. Filipits M: Mechanisms of cancer: multidrug resistance. Drug Discovery Today: Disease Mechanisms/Cancer 2: 229-234, 2004.

25. Cazin JL, Gosselin P, Cappelaere P, Robert J and Demaille A: Drug resistance in oncology: from concepts to applications. J Cancer Res Clin Oncol 119:76-86, 1992.

26. Ambudkar SV, Dey S and Hrycyna CA: Biochemical, cellular and pharmacological aspects of the multidrug transporter. Annu Rev Pharmacol Toxicol 39: 361-398, 1999.

27. Krishna R and Mayer LD: Multidrug resistance (MDR) in cancer. Mechanisms, reversal using modulators of MDR and the role of MDR modulators in influencing the pharmacokinetics of anticancer drug. European J of Pharmaceutical Sciences 11: 265-283, 2000.

28. Stavrovskaya AA: Cellular mechanisms of multidrug resistance of tumour cells. Biochemistry 65: 95-106, 2000.

29. Lewis AD, Forrester LM, Hayes JD, Wareing CJ, Carmichael J, Haris AL, Mooghen M and Wolf CR: Glutathione S-transferase isoenzymes in human tumours and tumour derived cell lines. Br J Cancer 60: 327-331, 1989.

30. Hao XY, Widersten M, Ridderstroom M, Hellman U and Mannervik B: Co-variation of glutathione transferase expression and cystatic drug resistance in HeLa cells: establishment of class $\mathrm{Mu}$ glutathione transferase M3-3 as the dominating isoenzymes. Biochem K 297: 59-67, 1994.

31. Austin CA and Marsh KL: Eukaryotic DNA topoisomerase II. Bioassays 20: 215-226, 1998.

32. Valkov NI and Sullivan DM: Drug resistance to DNA topoisomerase I and II inhibitors in human leukemia, lymphoma, and multiplemyeloma. Semin Hematol 34: 48-62, 1997.

33. Matsuo K, Kohno K, Takano H, Sato S, Kiue A and Kuwano M: Reduction of drug accumulation and DNA topoisomerase II activity in acquired teniposide-resistant human cancer KB cell lines. Cancer Res 50: 5819-5824, 1990.

34. Tan KB, Mattern MR, Eng WK, McCabe FL and Johnson RK: Nonproductive rearrangement of DNA topoisomerase I and II genes: Correlation with resistance to topoisomerase inhibitors. J Natl Cancer Inst 81: 1732-1735, 1989.

35. Chu G: Cellular responses to cisplatin. The roles of DNA-binding proteins and DNA repair. J Biol Chem 269: 787-790, 1994.

36. Lowe SW, Rusley HE, Jacks T and Houseman DE: p53 dependent apoptosis modulates the cytotoxicity of anticancer agents. Cell 74: 957-967, 1993.

37. Reed JC: Regulation of apoptosis by bcl-2 family proteins and its role in cancer and chemoresistance. Curr Opin Oncol 7: 541-546, 1995.

38. Sarkadi B, Homolya L, Szakács G and Váradi A: Human multidrug resistance ABCB and ABCG transporters: Participation in a Chemoimmunity defense sytem. Physiol Rev 86: 11791236, 2006.

39. Leslie EM, Deeley RG and Cole SPC: Multidrug resistance proteins: role of P-glycoprotein, MRP1, MRP2 and BCRP (ABCG2) in tissue defense. Toxicol Appl Pharmacol 204: 216-237, 2005.

40. Dean $\mathrm{M}$ and Allikmets R: Complete characterization of human $\mathrm{ABC}$ gene family. J Bioenerg Biomembr 33: 475-479, 2001.

41. Lage $\mathrm{H}$ : ABC-transporters: implications on drug resistance from microorganisms to human cancer. Int J of Antimicrob Agents 22: 188-199, 2003.

42. Borst P, Evers R, Kool M and Wijnholds J: The multidrug resistance protein family. Biochi Biophy Acta 1461: 347-357, 1999.

43. Bera TK, Lee S, Salvatore G, Lee B and Pastan I: MRP8, a new member of ABC transporter superfamily, identified by EST database mining and gene prediction program, is highly expressed in breast cancer. Mol Med 7: 509-516, 2001.

44. Bera TK, Iavarone C, Kumar V, Lee S, Lee B and Pastan I: MRP9, an unusual truncated member of the $\mathrm{ABC}$ transporter superfamily, is highly expressed in breast cancer. Proc Natl Acad Sci USA 99: 6997-7002, 2002. 
45. Doyle LA, Yang W, Abruzzo LV, Krogmann T, Gao Y, Rishi AK and Ross DD: .A multidrug resistance transporter from human MCF-7 breast cancer cells. Proc Natl Acad Sci USA 95: 15665-15670, 1998.

46. $\mathrm{Xu}$ J, Peng $\mathrm{H}$ and Zhang JT: Human multidrug transporter ABCG2, a target for sensitizing drug resistance in cancer chemotherapy. Curr Med Chem 14: 689-701, 2007.

47. Scheffer GL, Wijngaard PL, Flens MJ, Izquierdo MA, Slovak ML, Pinedo HM, Meijer CJ, Clevers HC and Scheper RJ: The drug resistance-related protein LRP is the human major vault protein. Nat Med 1: 578-582, 1995.

48. Kickhoefer VA, Rajavel KS, Scheffer GL, Dalton WS, Scheper RJ and Rome LH: Vaults are up-regulated in multidrug resistant cance cell lines J Biol Chem 273: 8971-8974, 1998.

49. Campos L, Guyotat D, Archimbaud E, Calmard-Oriol P, Tsuruo T, Troncy J, Treille D and Fiere D: Clinical significance of multidrug resistance P-glycoprotein expression on acute nonlymphoblastic leukemia cell at diagnostic. Blood 79: 473-476, 1992.

50. Niehans GA, Jaszcz W, Brunetto V, Perri RT, Gajl-Peczalska K, Wick MR, Tsuro T and Bloomfield CD: Immunohistochemical identification of P-glycoprotein in previously untreated diffuse large cell and immunoblastic lymphomas. Cancer Res 52: 3768-3775, 1992.

51. Chan HSL, Thorner P, Haddad G and Ling V: Immunohistochemical detection of Pglycoprotein prognostic correlation in soft tissue sarcoma of childhood. J Clin Oncol 8: 689704, 1990.

52. Chan HSL, Haddad G, Thorner PS, DeBoer G, Lin YP, Ondrusek N, Yeger H and Ling V: Pglycoprotein expression as a predictor of the outcome of therapy for neuroblastoma. New Engl J Med 325: 1608-1614, 1991.

53. Bradley G and Ling V: P-glycoprotein, multidrug resistance and tumour progression. Cancer Metastasis Rev 13: 223-233, 1994.

54. Aouali N, Eddabra L, Macadré $\mathrm{J}$ and Morjani H: Immunosupressors and reversion of multidrug resistance. Critical Reviews in Oncology/Hematology 1: 61-70, 2005.

55. Walker JE, Saraste M, Runswick MJ and Gay NJ: Distantly related sequences in the alphaand beta-subunits of ATP synthase, myosin, kinases and other ATP-requiring enzymes and a common nucleotide binding fold. EMBO J 1: 945-951, 1982.

56. Hung LW, Wang IX, Nikaiodo K, Liu PQ, Ames GFL and Kim SH: Crystal structure of the ATP-binding subinit of an ABC transporter. Nature 396: 703-707, 1998.

57. Tomboline G, Bartholomew LA, Gimi K, Tyndall GA and Senior AE: Synergy between conserved $\mathrm{ABC}$ signature ser residue in P-glycoprotein catalysis. J Biol Chem 279: 53635373, 2004.

58. Higgins CF and Linton KJ: The ATP swich model for ABC transporters. Nat Struct Mol Biol 11: 918-926, 2004.

59. Smith PC, Karpowich N, Millen L, Moody JE, Rosen J, Thomas PJ and Hunt JF: ATP binding to the motor domain from an $\mathrm{ABC}$ transporter drives formation of nucleotide sandwich dimer. Mol Cell 10: 139-149, 2002.

60. Hennessy M and Spiers JP: A primer on the mechanics of P-glycoprotein the multidrug transporter. Pharmac Research 55: 1-15, 2007.

61. Varma MVS, Ashokraj Y, Dey CS and Panchagnula R: P-glycoprotein inhibitors and their screening: a perspective from bioavailability enhancement. Pharm Res 48: 347-359, 2003.

62. Jones PM and George AM: A new structural model for P-glycoprotein. J Membr Biol 166: 133-147, 1998.

63. Higgins CF and Gottesman MM: Is the multidrug transporter a flippase? Trends Biochem Sci 17: 18-21, 1992.

64. Loo TW and Clarke DM: Do drug substrates enter the common drug-binding pocket of pglycoprotein through "gates"? Biochem Biophys Res Commun 329: 419-422, 2005.

65. Stein WD, Cardarelli C, Pastan I and Gottesman MM: Kinetic evidence suggesting that the multidrug transporter differentially handles influx and efflux of its substrates. Mol Pharmacol 45: 763-772, 1994.

66. Eckford PDW and Sharom FJ: The reconstituted P-glycoprotein multidrug transporter is a flippase for glucosylceramide and other simple glycosphingolipids. Biochem J 389: 517-526, 2005. 
67. Sharom FJ: The P-glycoprotein efflux pump: how does it transport drugs? J Membr Biol 160: 161-175, 1997.

68. Sarkadi B, Muller M, Homolya L, Hollo Z, Seprodi J, Germann UA, Gottesman MM, Price EM and Boucher RC: Interaction of bioactive hydrophobic peptides with the human multidrug transporter. FASEB J 8:766-770, 1994.

69. Sharom FJ, Yu X, DiDiodato G and Chu JW: Synthetic hydrophobic peptides are substrates for P-glycoprotein and stimulate drug transport. Biochem J 320: 421-428, 1996.

70. Cascarbi I: Role of pharmacogenetics of ATP-binding cassette transporters in the pharmacokinetics of drugs. Pharmacol \& Therapeutics 112: 457-473, 2006.

71. McDevitt and Callaghan R: How can we best use structural information on P-glycoprotein to design inhibitors? Pharmacol \& Therapeutics 113: 429-441, 2007.

72. Hevér A, Santelli-Rouver C, Brouant P, el Khyari S, Molnár J, Barra Y and Barbe J: Effect of new thioacridine derivatives on P-gp function and on $m d r l$ gene expression. Anticancer Res 18: 3053-3058, 1998.

73. Szabó D and Molnár J: The role of stereoselectivity of chemosensitizers in the reversal of multidug resistance of mouse lymphoma cells. Anticancer Res 18: 3039-3044, 1998.

74. Ugocsai K, Varga A, Molnár P, Antus S and Molnár J: Effects of selected flavonoids and carotenoids on drug accumulation and apoptosis induction in multidrug-resistant colon cancer cells expressing MDR1/LRP. In Vivo 19: 433-438, 2005

75. Gyémánt $\mathrm{N}$, Tanaka $\mathrm{M}$, Antus $\mathrm{S}$, Hohmann J, Csuka $\mathrm{O}$, Mándoky L and Molnár J: In vitro search for synergy between flavonoids and epirubicin on multidrug resistant cancer cells. In Vivo 19: 367-374, 2005.

76. Tsuruo T, Naito M, Tomida A, Fujita N, Mashima T, Sakamoto H and Haga N: Molecular targering therapy of cancer: drug resistance, apoptosis and survival signal. Cancer Sci 94: 1521, 2003.

77. Zamora JM, Pearce HL and Beck WT: Physical-chemical proporties shared by compounds that modulate multidrug resistance in human leukemic cells. Mol Pharmacol 33: 454-462, 1988.

78. Wang RB, Kuo CL, Lien LL and Lien EJ: Structure-activity realtionship: Analyses of Pglycoprotein substrates and inhibitors. J Clin Pharm Ther 28: 203-228, 2003.

79. Feng MR, Liebert M, Wedemeyer G, Grossman HB, Mancini WR, Williams M and Wagner JG: Effects of verapamil on the uptake and efflux of etoposide (VP16) in both sensitive and resistant cancer cells. Selective Cancer Ther 7: 75, 1992.

80. Lum BL, Kaubisch S, Fischer GA, Brown BW and Sikic BI: Effect of high-dose cyclosporine on etoposide pharmacodynamics in a trial to reverse P-glycoprotein (MDR1 gene) Cancer Chemoter Pharmacol 45: 305-311, 2001.

81. Berman A, McBridge M, Lin S, Menedez-Botet C and Tong W: Phase I trial of high-dose tamoxifen as a modulator of drug resistance in combination with daunorubicin in patients with relapsed or refractory acute leukemia. Leukemia 9: 1631-1637, 1995.

82. Ganapathi R and Grabowski D: Enhancement of sensitivity to adriamycin in resistant P388 leukemia by the calmodulin inhibitor trifluoperazine. Cancer Res 43: 3696-3699, 1983.

83. Lampidis TJ, Kolonias D, Tapiero H, Savaraj N and Cahn J: In vitro cardiac potencies of multidrug resistance modulators. Proc Am Assoc Cancer Res 31: 373, 1990.

84. Fracasso PM, Brady MF, Moore DH, Walker JL, Rose PG, Letvak L, Grogan TM and McGiure WP: Phase II study of paclitaxel and valspodar (PSC-833) in refractory ovarian carcinoma: a gynecologic oncology group study. J Clin Oncol 19: 2975-2982, 2001.

85. Yanagisawa T, Newman A and Coley H: Biricodar (VX-710; Incel): an effective chemosensitizer in neuroblastoma. Br J Cancer 80:1190-1196, 1999.

86. Pirker R, Keilhauer G, Raschack M, Lechner C and Ludwig H: Reversal of multidrug resistance in human KB cell lines by structural analogs of verapamil. Int J Cancer 45: 916$919,1990$.

87. Nawrath $\mathrm{H}$ and Raschack M: Effects of (-)-desmethoxyverapamil on heart and vascular smooth muscle. J Pharmacol Exp Ther 242: 1090-1097, 1987. 
88. Wandel C, Kim RB, Kajiji S, Guengerich P, Wilkinson GR and Wood AJ: P-Glycoprotein and cytochrome P-450 3A inhibition: Dissociation of inhibitory potencies. Cancer Res 59: 39443948, 1999.

89. Lum B and Gosland M: MDR expression in normal tissues: Pharmacologic implications for the clinic use of P-glycoprotein inhibitors. Hematol Oncol Clin North Am 9: 319-336, 1995.

90. Hendrikse NH, de Vries EG, Eriks-Fluks L, van der Graaf WT, Hospers GA, Willemsen AT, Vaalburg W and Franssen EJ: A new in vivo method to study P-glycoprotein transport in tumours and the blood-brain barrier. Cancer Res 10: 2411-2416, 1999.

91. Fakla I, Hevér A, Molnár J and Fischer J: Tomato lectin labels the $180 \mathrm{kD}$ glycoform of Pglycoprotein in rat brain capillary endothelia and $m d r$ tumour cells. Anticancer Res 18: 31073112, 1998.

92. Ozben T: Mechanisms and strategies to overcome multiple drug resistance in cancer. Febs Lett 12: 2903-2909, 2006.

93. Fox E and Bates SE: Tariquidar (XR9576): a P-glyoprotein drug efflux pump inhibitor. Expert Rev Anticancer Ther 4: 447-459, 2007.

94. Bardelmeijer HA, Ouwehand M, Beijnen JH, Schellens JH and van Tellingen O: Efficacy of novel P-glycoprotein inhibitors to increase the oral uptake of paclitaxel in mice. Invest New Drugs 3: 219-229, 2004.

95. Newman MJ, Rodarte JC, Benbatoul KD, Romano SJ, Zhang C, Krane S, Maron EJ, Uyeda RT, Dixon R, Guns ES and Meyer LD: Discovery and characterization of OC144-093, a novel inhibitor of P-glycoprotein-mediated multidrug resistance. Cancer Res 60: 2964-2972, 2000.

96. Starling JJ, Shepard RL and Cao J: Pharmacological characterization of LY335979: a potent cyclopropyl-dibenzosuberane modulator of P-glycoprotein. Adv Enzyme Regul 37: 335-347, 1997.

97. Cobbs CS, Harkins L, Samanta M, Gillespie GY, Bharara S, King PH, Nabors LB, Cobbs, and Britt WJ: Human cytomegalovirus infection and expression in human malignant glioma. Cancer Res 62: 3347-3350, 2002.

98. Huang G, Yan Q, Wang Z, Chen X, Zhang X, Gou Y and Li J: Human cytomegalovirus in neoplastic cells of Epstein-Barr virus negative Hodgkin's disease. Int J Oncol 21: 31-36, 2002.

99. Harkins L, Volk AL, Samantha M, Gillespie GY, Mikolaenko I, Britt WJ, Bland KI and Coobs CS: Specific localisation of human cytomegalovirus nucleic acids and proteins in human colorectal cancer. Lancet 360: 1557-1563, 2002.

100. Stinski MF, Malone CL, Hermiston TW and Liu B: Regulation of human cytomegalovirus transcription. In: Wagner EK (ed), Herpesvirus transcription and its control. CRC Press, Boca Raton, pp. 245-260, 1991.

101. Cinatl J Jr, Cinatl J, Vogel JU, Kotchetkov R, Driever PH, Kabickova H, Kornhuber B, Schowable D and Doerr HW: Persistent human cytomegalovirus infection induces drug resistance and alterations of programmed cell death in human neuroblastoma cells. Cancer Res 58: 367-372, 1998.

102. Cinatl J, Scholz M, Kotchetkov R, Vogel JU and Doerr HW: Molecular mechanisms of the modulatory effects of CMV infection in tumour cell biology. Trends in Molecular Medicine 1: 19-23, 2004.

103. Szatmári I, Martinek TA, Lázár L and Fülöp F: Tetrahedron 59: 2877-2884, 2003.

104. Senouchi K, Nakai H, Nakayama Y, Odagaki Y, Sakaki K, Kato M, Maruyama T, Miyazaki T, Ito H, Kamiyasu K, Kim S, Kawamura M and Hamanaka N: New orally active serine protease inhibitor. J Med Chem 38: 2521-2523, 1995.

105. European Patent No 1432717 B1: Substituted disiloxanes method for the production thereof and the use thereof for reversal of multidrug resistance (MDR).

106. Cornwell MM, Pastan I and Gottesmann M: Certain calcium channel blockers bind specifically to multidrug-resistant human KB carcinoma membrane vesicles and inhibit drug binding to P-glycoprotein. J Biol Chem 262: 2166-2170, 1987.

107. Gruber A, Peterson C and Reizenstein P: D-verapamil and L-verapamil are equally effective in increasing vincristine accumulation in leukemic cells in vitro. Int J Cancer 41: 224-226, 1988. 
108. Eliooulos GM and Moellering RC: Antimicrobial combinationa. In: Antibiotics in laboratory medicine. (Lorian V (eds). Williams and Wilkins), USA, pp. 432-433, 1980.

109. van Asperen $\mathrm{J}$, van Tellingen $\mathrm{O}$ and Beijnen $\mathrm{JH}$ : Determination of doxorubicin and metabolism in murine specimens by high performance liquid chromatography. J of Chrom $B$ 712: 129-143, 1998.

110. Motohashi N, Kurihara T, Satoh K, Sakagami H, Mucsi I, Pusztai R, Szabó M and Molnár J: Antitumour activity of benzo[ $\alpha]$ phenothiazines. Anticancer Res 19: 1837-1842, 1999.

111. Vermes I, Haanen C and Reutelingsperger C: Flow cytometry of apoptotic cell death. J Immunol Methods 243: 167-190, 2000.

112. Ribble D, Goldstein NB, Norris DA and Shellman YG: A simple technique for quantifying apoptosis in 96-well plates. BMC Biotechnol 5: 12, 2005.

113. Evans JF and Taylor SE: Pro-inflammatory, tumour-promoting and antitumour diterpenes of the plant families Euphorbiaceae and Thymelaeaceae. Prog Chem Org Nat Prod 44: 1-99, 1983.

114. Valente C, Ferreira MJU, Abreu PM, Gyémánt N, Ugocsai K, Hohmann J and Molnár J: Pubescenes, jatrophane diterpenes from Euphorbia pubescens with multidrug resistance reversing activity on mouse lymphoma cells. Planta Med 70: 81-84, 2004.

115. Madureira AM, Gyémánt N, Ugocsai K, Ascenso JR, Abreu PM, Hohmann J, Molnár J and Ferreira MJU: Rearranged jatrophane-type diterpenes from Euphorbia species. Evaluation of their effect on the reversal of multidrug resistance. Planta Med 70: 45-49, 2004.

116. Hohmann $\mathrm{J}$ and Molnár J: Euphorbiaceae diterpenes: plant toxins or promising molecules for the therapy? Acta Pharm Hung 74: 149-157, 2004.

117. Dimmock JR, Sidhu KK, Chen M, Li J, Quail JW, Allen TM and Kao GY: Synthesis and cytotoxic evaluation of some cyclic arylidene ketones and related oximes, oxime esters, and analogs. Can. Journal of Pharmaceutical Sciences 83: 852-858, 1994.

118. Dimmock, JR, Baker GB and Sutherland RG: Evaluation of 1-phenyl-1,3-undecadien-5-one and related compounds for antineoplastic and cytotoxic activity. Canadian Journal of Pharmaceutical Sciences 10: 53-59, 1975.

119. Kars MD, Iseri ÖD, Gündüz U, Ural AU, Arpaci F and Molnár J: Develpment of rational in vitro models for drug resistance in breast cancer and modulation of MDR by selected compounds. Anticancer Res 26: 4559-4568, 2006.

120. Bossert F, Meyer H and Wehinger E: 4-Aryldihydropyridine, a new class of highly active calcium antagonists. Angew Chem Int Ed Engl 20: 762-769, 1981.

121. Godfrain T, Miller R and Wibo M: Calcium antagonism and calcium entry blockade. Pharmacol Rev 38: 321-416, 1986.

122. Kharkar PS, Desai B, Gaveria H, Varu B, Loriya R, Naliapara Y, Shah A and Kulkarni VM: Three-dimensional quantitative structure-activity realtionship of 1,4-dihydropyridines as antitubercular agents. J Med Chem 45: 4858-4867, 2002.

123. Kawase M, Shah A, Gaveriya H, Motohashi N, Sakagami H, Varga A and Molnár J: 3,5Dibenzoyl-1,4- dihydropyridines: synthesis and MDR reversal in tumour cells. Bioorg Med Chem 10: 1051-1055, 2002.

124. Morshed SR, Hashimoto K, Murotani Y, Kawase M, Shah A, Satoh K, Kikuchi H, Nishikawa $\mathrm{H}$, Maki J and Sakagami H: Tumour-specific cytotoxicity of 3,5-dibenzoyl-1,4dihydropyridines. Anticancer Res 25: 2033-2038, 2005.

125. Saponara S, Kawase M, Shah A, Motohashi N, Molnár J, Ugocsai K, Sparagli G and Fusi F: 3,5- Dibenzoyl-4-(3-phenoxyphenyl)-1,4- dihydro-2,6-dimethylpyridine (DP7) as a new multidrug resistance reverting agent devoid of effects on vascular smooth muscle contractility. Br J Pharmacol 141: 415-422, 2004.

126. Ramu A and Ramu N: Reversal of multidrug resistance by phenothiazines and structurally related compounds. Cancer Chemother Pharmacol 30: 165-173, 1992.

127. Molnár J, Molnár A, Mucsi I, Pintér O, Nagy B, Varga A and Motohashi N: Reversal of multidrug resistance in mouse lymphoma cells by phenothiazines. In Vivo 17: 145-150, 2003.

128. Molnár J, Pusztai R, Hevér A, Nagy $\mathrm{S}$ and Motohashi N: Effects of two benzo(a)phenothiazines on multidrug resistance (mdr) and tumour antigen expression. Anticancer Res 15: 2013-2016, 1995. 
129. Motohashi N, Kawase M, Saito S and Sakagami H: Antitumour potential and possible targets of phenothiazine-related compounds. Curr Drug Targets 1: 237-245, 2000.

130. Weselowska O, Molnár J, Motohashi N and Michalak K: Inhibition of P-gp transport function by N-acylphenothiazines. Anticancer Res 22: 2863-2868, 2002.

131. Flores VC, Keyzer H, Kim HK and Molnár J: Interaction of pronated anticancer thiazines with water-insoluble phospholipids and antineoplastic agents. Anticancer Res 22: 959-968, 2002.

132. Chiosis G, Rodina A and Moulick K: Emerging Hsp90 inhibitors: from discovery to clinic. Anticancer Agents Med Chem 6: 1-8, 2006.

133. Molnár J, Gyémánt N, Mucsi I, Molnár A, Szabó M, Körtvélyesi T, Varga A, Molnár P and Tóth G: Modulation of multidrug resistance and apoptosis of cancer cells by selected carotenoids. In Vivo 18: 237-244, 2004.

134. Orosz A, Szabó A, Szeman G, Somlai Cs, Janaky T and Penke B: Peptides with pharmaceutical activity, process for the preparation thereof and pharmaceutical composition containing the same. PCT Int. Appl. WO PCT/HU2005/000069 Hungarian Patent, 2005. WO 2006/092640

135. Orosz A, Szabo A, Szeman G, Somlai Cs, Janaky T and Penke B: New anticancer peptide analog compounds targeting the tumour Hsp90 protein have no toxic effect on normal cells. $11^{\text {th }}$ Word Conference on Lung Cancer, Barcelona, Spain, 3-6 July, 2005.

136. Omura S: Macrolide Antibiotics, Ac Press, Orlando, Florida, 1984.

137. Didziapetris R, Japertas P, Avdeef A and Petrauskas A: Classification analysis of Pglycoprotein substrate specificity. J Drug Target 11: 391-406, 2003.

138. Minotti G, Menna P, Salvatorelli E, Cairo G and Gianni L: Anthracyclines: molecular advances and pharmacologic develpments in antitumour activity and cardiotoxicity. Pharmacol Rev 56: 185-229, 2004.

139. Gewirtz DA: A critical evaluation of the mechanisms of action proposed for the antitumour effects of the anthracycline antibiotics adriamycin and daunorubicin. Biochem Pharmacol 57: 727-741, 1999.

140. Hartwell JL: Plants used against cancer. A survey. J Nat Prod 62:153-205, 1969.

141. Schmidt RJ and Evans FJ: Skin irritants of the sun spurge (Euphorbia helioscopia L.). Contact Dermatitis 6: 204-210, 1980.

142. Evans JF and Taylor SE: Pro-inflammatory, tumour-promoting and antitumour diterpenes of the plant families Euphorbiaceae and Thymelaeaceae. Prog Chem Org Nat Prod 44: 1-99, 1983.

143. Hohmann J, Vass A, Günther G, Dombi G, Blazsó G, Falkay G, Máthé I and Jerkovich G: Jatrophane diterpenoids from Euphorbia peplus. Phytochemistry 51: 673-677, 1999.

144. Hohmann J, Molnár J, Rédei D, Evanics F, Forgó P, Kálmán A, Argay G and Szabó P: Discovery and biological evaluation of a new family of potent modulators of multidrug resistance: reversal of multidrug resistance of mouse lymphoma cells by new natural jatrophane diterpenoids isolated from Euphorbia species. J Med Chem 45: 2425-2431, 2002.

145. Tsao As, Kim ES and Hong WK: Chemoprevention of cancer. CA Cancer J Clin 54: 150-180, 2004.

146. Takasaki M, Konoshima T, Murata Y, Sugiura M, Nishino H, Tokuda H, Matsumoto K, Kasai $\mathrm{R}$ and Yamasaki K: Anticarcinogenic activity of natural sweeteners, cucurbitane glycosides, from Momordica grosvenori. Cancer Lett 198: 37-42, 2003.

147. Wattenberg LW: Chemoprevention of cancer. Prev Med 25: 44-45, 1996.

148. Cinethl J Jr, Vogel JU, Kotchetkov R, Doerr HW: Oncomodulatory signals by regulatory proteins encoded by human cytomegalovirus: novel role for viral infection in tumour progression. FEMS Microbiol Rev 28: 59-77, 2004.

149. Molnár J, Szabó D, Pusztai R, Mucsi I, Berek L. Ocsovszki I, Kawata E and Shoyama Y: Membrane associated antitumour effects of crocine-, ginsenoside-and cannabinoid derivatives. Anticancer Res 20: 861-868, 2000.

150. Konoshima T, Takasaki T, Tokuda H, Morimoto S, Tanaka H, Kawata E, Xuan LJ, Saito H, Sugiura M, Molnár J and Shoyama Y: Crocin and crocetin derivatives inhibit skin tumour promotion in mice. Phytotherapy Res 12: 400-404, 1998. 